\title{
Blue-Emitting Platinum(II) Complexes Bearing both Pyridylpyrazolate Chelate and Bridging Pyrazolate Ligands: Synthesis, Structures, and Photophysical Properties
}

\author{
Sheng-Yuan Chang, Jing-Lin Chen, and Yun Chi* \\ Department of Chemistry, National Tsing Hua University, Hsinchu 300, Taiwan \\ Yi-Ming Cheng, Gene-Hsiang Lee, Chang-Ming Jiang, and Pi-Tai Chou* \\ Department of Chemistry and Instrumentation Center, National Taiwan University, \\ Taipei 106, Taiwan
}

Received August 9, 2007

\begin{abstract}
A new $\mathrm{Pt}(\mathrm{II})$ dichloride complex [Pt(fppzH) $\left.\mathrm{Cl}_{2}\right]$ (1), in which fppzH = 3-(trifluoromethyl)-5-(2-pyridyl)pyrazole, was prepared by the treatment of a pyridylpyrazole chelate fppz $\mathrm{H}$ with $\mathrm{K}_{2} \mathrm{PtCl}_{4}$ in aqueous $\mathrm{HCl}$ solution. Complex 1 could further react with its parent pyrazole $(\mathrm{pzH})$, 3,5-dimethylpyrazole $(\mathrm{dmpzH})$, or 3,5-di-tert-butylpyrazole $(\mathrm{dbpzH})$ to afford the monometallic [Pt(fppz)(pzH)Cl] (2), [Pt(fppz)(dmpzH)Cl] (3), $\left[\mathrm{Pt}(\mathrm{fppz})(\mathrm{dmpzH})_{2}\right] \mathrm{Cl}(4)$, or two structural isomers with formula $[\mathrm{Pt}(\mathrm{fppz})(\mathrm{dbpz} \mathrm{H}) \mathrm{Cl}](\mathbf{5 a}, \mathbf{b})$. Single-crystal X-ray diffraction studies of $\mathbf{2}, \mathbf{4}$, and $\mathbf{5 a}, \mathbf{b}$ revealed a square planar $\mathrm{Pt}(\mathrm{II})$ framework, among which a strong interligand hydrogen bonding occurred between fppz and pzH ligands in 2. This interligand $\mathrm{H}$-bonding is replaced by dual $\mathrm{N}-\mathrm{H} \cdots \mathrm{Cl}$ interaction in $\mathbf{4}$ and both intermolecular $\mathrm{N}-\mathrm{H} \cdots \mathrm{O}$ (with THF solvate) and $\mathrm{N}-\mathrm{H} \cdots \mathrm{Cl}$ interaction in $5 \mathrm{a}, \mathrm{b}$, respectively; the latter are attributed to the bulky tert-butyl substituents that force the $\mathrm{dbpzH}$ ligand to adopt the perpendicular arrangement. Furthermore, complex 2 underwent rapid deprotonation in basic media to afford two isomeric complexes with formula $[\mathrm{Pt}(\mathrm{fppz})(\mu-\mathrm{pz})]_{2}$ $(6 \mathbf{a}, \mathbf{b})$, which are related to each other according to the spatial orientation of the fppz chelates, i.e., trans- and cis-isomerism. Similar reaction exerted on $\mathbf{3}$ afforded isomers $7 \mathbf{a}, \mathbf{b}$. Both $\mathbf{6 a}, \mathbf{b}(\mathbf{7} \mathbf{a}, \mathbf{b})$ are essentially nonemissive in room-temperature fluid state but afford strong blue phosphorescence in solid state prepared via either vacuumdeposited thin film or $77 \mathrm{~K} \mathrm{CH}_{2} \mathrm{Cl}_{2}$ matrix. As also supported by the computational approaches, the nature of emission has been assigned to be ligand-centered triplet $\pi \pi^{*}$ mixed with certain metal-to-ligand charge-transfer character.
\end{abstract}

\section{Introduction}

Luminescent heavy metal complexes are likely to play a pivotal role in tomorrow's displays and solid-state lighting equipment through the so-called phosphorescent organic light-emitting diode (OLED) technology. Phosphorescent materials generally consist of third-row, transition metal complexes, among which the most effective materials are ascribed to those possessing Os(II), Ir(III), and Pt(II) central metal atoms. ${ }^{1}$ These complexes produce bright emission from excited states with an increased contribution from the metal-to-ligand charge transfer (MLCT) character,

* To whom correspondence should be addressed. E-mail: ychi@ mx.nthu.edu.tw (Y.C.), chop@ntu.edu.tw (P.-T.C.). Fax: +88635720864 (Y.C.), +886 223695208 (P.-T.C.).

11202 Inorganic Chemistry, Vol. 46, №. 26, 2007 which effectively breaks down the spin conservation rule, facilitating a change in multiplicity and the subsequent radiative transition from the triplet state to the ground state. ${ }^{2}$ Such phosphorescent systems possess a major advantage over their fluorescent counterparts, for which only the singlet excitons can be harvested from the viewpoint of spin conservation and thus are less efficient in luminescence properties.

(1) (a) Fuhrmann, T.; Salbeck, J. MRS Bull. 2003, 28, 354. (b) Holder, E.; Langeveld, B. M. W.; Schubert, U. S. Adv. Mater. 2005, 17, 1109. (c) Yersin, H. Top. Curr. Chem. 2004, 241, 1. (d) Chi, Y.; Chou, P. T. Chem. Soc. Rev. 2007, 36, 1421.

(2) (a) Matsushita, T.; Asada, T.; Koseki, S. J. Phys. Chem. A 2006, 110, 13295. (b) Forster, L. S. Coord. Chem. Rev. 2006, 250, 2023. (c) Matsushita, T.; Asada, T.; Koseki, S. J. Phys. Chem. C. 2007, 111, 6897.

10.1021/ic701586c CCC: $\$ 37.00$ C 2007 American Chemical Society Published on Web 11/21/2007 
In view of the design of high-efficiency luminescent materials, both the $\operatorname{Ir}(\mathrm{III})$ and $\mathrm{Os}(\mathrm{II})$ complexes with $\mathrm{d}^{6}$ electronic configuration are of prime candidates. ${ }^{3}$ This is due to the fact that they generally possess an octahedral geometry with mutually orthogonal ligand chromophores, for which the interligand nonbonding interactions are significantly reduced, such that the respective emission can be produced in a rather effective manner. Since the Os(II) metal center is much easier to be oxidized, i.e., it possesses a lower oxidation potential, the corresponding Os(II) complexes tend to afford much red-shifted emission signals due to the dominance of the MLCT contribution versus the intraligand $\pi \pi^{*}$ (or ILCT) transition. Conversely, the isoelectronic Ir(III) metal element should be less easy to undergo oxidation due to its excessive positive charge density at the metal center, which in turn affords a greater gap for the anticipated MLCT transition. As a result, the $\operatorname{Ir}(\mathrm{III})$ system, in theory, should be suitable for the preparation of greater energy gap, blue phosphorescent materials. ${ }^{4}$

In yet another approach, as $\mathrm{Pt}(\mathrm{II})$ should possess higher oxidation state than that of Os(II) as well as the isoelectronic $\operatorname{Ir}(\mathrm{I})$ systems, ${ }^{5}$ the reduction of the MLCT contribution is expected and hence may be suited to achieve blue phosphorescence by employing suitable ligand design. However, in contrast to the previously mentioned $\mathrm{d}^{6} \mathrm{com}-$ plexes, the $\mathrm{d}^{8} \mathrm{Pt}(\mathrm{II})$ complexes generally possess alternative planar molecular geometry. Significant intermolecular interactions are thus expected in both fluid and solid states, ${ }^{6}$ resulting in complications in assessing their fundamental photophysical properties. One is the occurrence of unwanted bathochromic emission, which originates from

(3) (a) Chou, P. T.; Chi, Y. Eur. J. Inorg. Chem. 2006, 3319. (b) Chou, P. T.; Chi, Y. Chem.-Eur. J. 2007, 13, 380.

(4) (a) Nazeeruddin, M. K.; Wegh, R. T.; Zhou, Z.; Klein, C.; Wang, Q.; De Angelis, F.; Fantacci, S.; Graetzel, M. Inorg. Chem. 2006, 45, 9245. (b) Lo, S. C.; Shipley, C. P.; Bera, R. N.; Harding, R. E.; Cowley, A. R.; Burn, P. L.; Samuel, I. D. W. Chem. Mater. 2006, 18 5119. (c) Tamayo, A. B.; Garon, S.; Sajoto, T.; Djurovich, P. I.; Tsyba, I. M.; Bau, R.; Thompson, M. E. Inorg. Chem. 2005, 44, 8723. (d) Takizawa, S. Y.; Nishida, J. I.; Tsuzuki, T.; Tokito, S.; Yamashita, Y. Inorg. Chem. 2007, 46, 4308. (e) Dedeian, K.; Shi, J.; Forsythe, E.; Morton, D. C.; Zavalij, P. Y. Inorg. Chem. 2007, 46, 1603. (f) Chin, C. S.; Eum, M. S.; Kim, S. Y.; Kim, C.; Kang, S. K. Eur. J. Inorg. Chem. 2007, 372. (g) Yang, C. H.; Cheng, Y. M.; Chi, Y.; Hsu, C. J.; Fang, F. C.; Wong, K. T.; Chou, P. T.; Chang, C. H.; Tsai, M. H.; Wu, C. C. Angew. Chem., Int. Ed. 2007, 46, 2418.

(5) Fang, C. H.; Chen, Y. L.; Yang, C. H.; Chi, Y.; Yeh, Y. S.; Li, E. Y.; Cheng, Y. M.; Hsu, C. J.; Chou, P. T.; Chen, C. T. Chem.-Eur. J. 2007, 13, 2686.

(6) (a) Wadas, T. J.; Wang, Q. M.; Kim, Y. J.; Flaschenreim, C.; Blanton, T. N.; Eisenberg, R. J. Am. Chem. Soc. 2004, 126, 16841. (b) Lu, W.; Chan, M. C. W.; Zhu, N.; Che, C. M.; Li, C.; Hui, Z. J. Am. Chem. Soc. 2004, 126, 7639. (c) Pomestchenko, I. E.; Castellano, F. N. J. Phys. Chem. A 2004, 108, 3485. (d) Wong, W.-Y.; He, Z.; So, S.-K.; Tong, K.-L.; Lin, Z. Organometallics 2005, 24, 4079. (e) Yam, V. W. W.; Chan, K. H. Y.; Wong, K. M. C.; Chu, B. W. K. Angew. Chem., Int. Ed. 2006, 45, 6169. (f) He, Z.; Wong, W.-Y.; Yu, X.; Kwok, H.-S.; Lin, Z. Inorg. Chem. 2006, 45, 10922. (g) Lu, W.; Roy, V. A. L.; Che, C. M. Chem. Commun. 2006, 3972. (h) Forniés, J.; Fuertes, S.; Martín, A.; Sicilia, V.; Lalinde, E.; Moreno, M. T. Chem.Eur. J. 2006, 12, 8253. (i) Field, J. S.; Haines, R. J.; Ledwaba, L. P.; McGuire, R., Jr.; Munro, O. Q.; Low, M. R.; McMillin, D. R. Dalton Trans. 2007, 192. (j) Scaffidi-Domianello, Y. Y.; Nazarov, A. A.; Haukka, M.; Galanski, M.; Keppler, B. K.; Schneider, J.; Du, P.; Eisenberg, R.; Kukushkin, V. Y. Inorg. Chem. 2007, 46, 4469. (k) Zhou, G.-J.; Wang, X.-Z.; Wong, W.-Y.; Yu, X.-M.; Kwok, H.-S.; Lin, Z. J. Organomet. Chem. 2007, 692, 3461. the so-called metal-metal-bond-to-ligand charge transfer (MMLCT) transition, a result of strong stacking interaction among these planar molecules upon crystallization in the solid state. ${ }^{7}$

In this work, we report the synthesis and characterization of a new family of emissive complexes involving the Pt(II) metal element in anticipation of seeing efficient blue phosphorescence with fair color chromaticity. We present the strategy of molecular design as well as methodologies of how to avoid the $\mathrm{Pt}(\mathrm{II})$ packing interaction in solid state, such that decent blue phosphorescence can be achieved. Special attention is paid to several important issues such as synthetic pathways, theoretical interpretation, and how to broaden the reaction scope using the new intermediate with formula $\left[\mathrm{Pt}(\mathrm{fppzH}) \mathrm{Cl}_{2}\right](\mathbf{1})$, fppzH $=3$-(trifluoromethyl)-5(2-pyridyl)pyrazole.

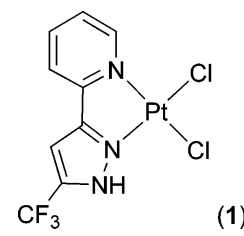

\section{Experimental Section}

General Procedures. All reactions were performed under nitrogen atmosphere. Solvents were distilled from appropriate drying agents prior to use. Metal reagent $\mathrm{K}_{2} \mathrm{PtCl}_{4}$ was ordered online from PMO Pty Ltd., while pyrazole and 3,5-dimethylpyrazole were purchased from Aldrich. Commercially available reagents were used without further purification unless otherwise stated. All reactions were monitored by precoated TLC plates $(0.20 \mathrm{~mm}$ with fluorescent indicator $\mathrm{UV}_{254}$ ). Flash column chromatography was carried out using silica gel (230-400 mesh). Mass spectra were obtained on a JEOL SX-102A instrument operating in electron impact (EI) or fast atom bombardment (FAB) mode. ${ }^{1} \mathrm{H}$ and ${ }^{13} \mathrm{C}$ NMR spectra were recorded on a Varian Mercury-400 or an INOVA-500 instrument; chemical shifts are quoted with respect to the internal standard tetramethylsilane for ${ }^{1} \mathrm{H}$ and ${ }^{13} \mathrm{C}$ NMR data. Elemental analysis was carried out with a Heraeus CHN-O Rapid Elementary Analyzer.

Synthesis of [ $\left.\mathbf{P t}(\mathbf{f p p z H}) \mathrm{Cl}_{2}\right](\mathbf{1})$. A mixture of $\mathrm{K}_{2} \mathrm{PtCl}_{4}(210 \mathrm{mg}$, $0.50 \mathrm{mmol}$ ) and 3-(trifluoromethyl)-5-(2-pyridyl)pyrazole (fppzH, $106 \mathrm{mg}, 0.50 \mathrm{mmol})$ in a solution of $4 \mathrm{M} \mathrm{HCl}(1 \mathrm{~mL})$ and water $(15 \mathrm{~mL})$ was refluxed for about $2 \mathrm{~h}$. After lowering of the temperature to RT (room temperature), the precipitate was filtered off and washed with diethyl ether and hexane. The solid was separated using silica gel thin layer chromatography eluting with pure $\mathrm{CH}_{2} \mathrm{Cl}_{2}$, giving yellow [ $\left.\mathrm{Pt}(\mathrm{fppzH}) \mathrm{Cl}_{2}\right](\mathbf{1}, 185 \mathrm{mg}, 0.39 \mathrm{mmol}$, $77 \%)$ and orange $\left[\mathrm{Pt}(\mathrm{fppz})_{2}\right](8 \mathrm{mg}, 0.01 \mathrm{mmol}, 3 \%)$.

Spectral data for 1: MS (FAB, $\left.{ }^{195} \mathrm{Pt}\right) \mathrm{m} / \mathrm{z}, 479\left(\mathrm{M}^{+}\right), 443\left(\mathrm{M}^{+}-\right.$ $\mathrm{HCl}) ;{ }^{1} \mathrm{H}$ NMR $\left(400 \mathrm{MHz}\right.$, acetone- $\left.d_{6}, 298 \mathrm{~K}\right) \delta 9.45\left(\mathrm{~d}, J_{\mathrm{HH}}=\right.$ $6.0 \mathrm{~Hz}, 1 \mathrm{H}), 8.38\left(\mathrm{dd}, J_{\mathrm{HH}}=7.6,7.2 \mathrm{~Hz}, 1 \mathrm{H}\right), 8.30\left(\mathrm{~d}, J_{\mathrm{HH}}=7.6\right.$ $\mathrm{Hz}, 1 \mathrm{H}), 7.88(\mathrm{~s}, 1 \mathrm{H}), 7.77\left(\mathrm{dd}, J_{\mathrm{HH}}=7.2,6.0 \mathrm{~Hz}, 1 \mathrm{H}\right) ;{ }^{19} \mathrm{~F} \mathrm{NMR}$ $\left(470 \mathrm{MHz}\right.$, acetone- $\left.d_{6}, 298 \mathrm{~K}\right) \delta-61.12\left(\mathrm{~s}, \mathrm{CF}_{3}\right)$. Anal. Calcd for $\mathrm{C}_{9} \mathrm{H}_{6} \mathrm{Cl}_{2} \mathrm{~F}_{3} \mathrm{~N}_{3} \mathrm{Pt}:$ C, 22.56; H, 1.26; N, 8.77. Found: $\mathrm{C}, 22.37 ; \mathrm{H}$, $1.48 ; \mathrm{N}, 8.59$.

(7) (a) Lai, S. W.; Che, C. M. Top. Curr. Chem. 2004, 241, 27. (b) Houlding, V. H.; Miskowski, V. M. Coord. Chem. Rev. 1991, 111, 145. (c) Miskowski, V. M.; Houlding, V. H. Inorg. Chem. 1991, 30, 4446. 
Synthesis of [Pt(fppz)(pzH)(Cl)] (2). [(fppzH) $\left.\mathrm{PtCl}_{2}\right](150 \mathrm{mg}$, $0.31 \mathrm{mmol}$ ) and pyrazole (pzH, $47 \mathrm{mg}, 0.69 \mathrm{mmol})$ in $30 \mathrm{~mL}$ of $\mathrm{CH}_{2} \mathrm{Cl}_{2}$ was stirred at room temperature for $12 \mathrm{~h}$. Then the solution was washed with deionized water and concentrated to dryness under reduced pressure. Further purification was conducted by silica gel thin layer chromatography eluting with $\mathrm{CH}_{2} \mathrm{Cl}_{2}$, followed by recrystallization from a mixture of $\mathrm{CH}_{2} \mathrm{Cl}_{2}$ and hexanes, giving $[\mathrm{Pt}(\mathrm{fppz})(\mathrm{pzH}) \mathrm{Cl}]$ as yellow needles $(\mathbf{2}, 110 \mathrm{mg}, 0.22 \mathrm{mmol}$, $68 \%)$.

Spectral data for 2: MS (FAB, $\left.{ }^{195} \mathrm{Pt}\right) \mathrm{m} / z, 511\left(\mathrm{M}^{+}\right)$; ${ }^{1} \mathrm{H}$ NMR $\left(400 \mathrm{MHz}, \mathrm{CD}_{2} \mathrm{Cl}_{2}, 298 \mathrm{~K}\right) \delta 15.29(\mathrm{br}, 1 \mathrm{H}), 9.46\left(\mathrm{~d}, J_{\mathrm{HH}}=6.2\right.$ $\mathrm{Hz}, 1 \mathrm{H}), 8.50(\mathrm{br}, 1 \mathrm{H}), 7.97\left(\mathrm{dd}, J_{\mathrm{HH}}=7.8,7.4 \mathrm{~Hz}, 1 \mathrm{H}\right), 7.89$ (br, $1 \mathrm{H}), 7.68\left(\mathrm{~d}, J_{\mathrm{HH}}=7.8 \mathrm{~Hz}, 1 \mathrm{H}\right), 7.31\left(\mathrm{dd}, J_{\mathrm{HH}}=7.4,6.2 \mathrm{~Hz}, 1 \mathrm{H}\right)$, $6.97(\mathrm{~s}, 1 \mathrm{H}), 6.48(\mathrm{br}, 1 \mathrm{H}) ;{ }^{19} \mathrm{~F}$ NMR $\left(470 \mathrm{MHz}\right.$, acetone- $d_{6}, 298$ K) $\delta-61.52\left(\mathrm{~s}, \mathrm{CF}_{3}\right)$. Anal. Calcd for $\mathrm{C}_{12} \mathrm{H}_{9} \mathrm{ClF}_{3} \mathrm{~N}_{5} \mathrm{Pt}$ : C, 28.22; H, 1.78; N, 13.71. Found: C, 28.03; H, 1.98; N, 13.36.

Reaction with 3,5-Dimethylpyrazole. [(fppzH) $\left.\mathrm{PtCl}_{2}\right](150 \mathrm{mg}$, $0.31 \mathrm{mmol})$ and 3,5-dimethylpyrazole (dmpzH, $75 \mathrm{mg}, 0.78 \mathrm{mmol})$ in $30 \mathrm{~mL}$ of $\mathrm{CH}_{2} \mathrm{Cl}_{2}$ was stirred at room temperature for $12 \mathrm{~h}$. Then the solution was washed with water and concentrated to dryness under reduced pressure. Further purification was conducted by repeated recrystallization from methanol solution, from which the less soluble yellow and the relatively more soluble pale-yellow crystalline solids were identified to be $[\mathrm{Pt}(\mathrm{fppz})(\mathrm{dmpzH}) \mathrm{Cl}](\mathbf{3}, 20$ $\mathrm{mg}, 0.04 \mathrm{mmol}, 12 \%)$ and $\left[\mathrm{Pt}(\mathrm{fppz})(\mathrm{dmpzH})_{2}\right] \mathrm{Cl}(\mathbf{4}, 100 \mathrm{mg}, 0.16$ mmol, 52\%), respectively.

Spectral data for 3: MS (FAB, $\left.{ }^{195} \mathrm{Pt}\right) \mathrm{m} / \mathrm{z} 537(\mathrm{M}-1)^{+} ;{ }^{1} \mathrm{H}$ NMR $\left(400 \mathrm{MHz}, \mathrm{CD}_{2} \mathrm{Cl}_{2}, 298 \mathrm{~K}\right) \delta 12.21(\mathrm{br}, 1 \mathrm{H}), 8.76\left(\mathrm{~d}, J_{\mathrm{HH}}=\right.$ $6.5 \mathrm{~Hz}, 1 \mathrm{H}), 7.75\left(\mathrm{t}, J_{\mathrm{HH}}=7.8,7.2 \mathrm{~Hz}, 1 \mathrm{H}\right), 7.44\left(\mathrm{~d}, J_{\mathrm{HH}}=7.8\right.$ $\mathrm{Hz}, 1 \mathrm{H}), 6.87\left(\mathrm{t}, J_{\mathrm{HH}}=7.2,6.5 \mathrm{~Hz}, 1 \mathrm{H}\right), 6.84(\mathrm{~s}, 1 \mathrm{H}), 5.94(\mathrm{br}$, 1H), 2.41 (s, 3H), 2.15 (s, 3H); ${ }^{19} \mathrm{~F}$ NMR (470 MHz, $\mathrm{CD}_{2} \mathrm{Cl}_{2}, 298$ K) $\delta-61.32\left(\mathrm{~s}, \mathrm{CF}_{3}\right)$. Anal. Calcd for $\mathrm{C}_{14} \mathrm{H}_{13} \mathrm{ClF}_{3} \mathrm{~N}_{5} \mathrm{Pt}$ : C, 31.21; H, 2.43; N, 13.00. Found: C, 31.03; H, 2.60; N, 13.10.

Spectral data for 4: MS (FAB, $\left.{ }^{195} \mathrm{Pt}\right) \mathrm{m} / \mathrm{z} 599(\mathrm{M}-\mathrm{Cl})^{+}, 598$ $(\mathrm{M}-\mathrm{HCl})^{+} ;{ }^{1} \mathrm{H} \mathrm{NMR}\left(400 \mathrm{MHz}, \mathrm{CD}_{2} \mathrm{Cl}_{2}, 298 \mathrm{~K}\right) \delta 15.13(\mathrm{br}$, $1 \mathrm{H}), 14.53(\mathrm{br}, 1 \mathrm{H}), 7.97(\mathrm{~m}, 1 \mathrm{H}), 7.74\left(\mathrm{~d}, J_{\mathrm{HH}}=7.6 \mathrm{~Hz}, 1 \mathrm{H}\right)$, $7.08(\mathrm{~m}, 2 \mathrm{H}), 6.90(\mathrm{~s}, 1 \mathrm{H}), 6.08(\mathrm{br}, 1 \mathrm{H}), 6.04(\mathrm{br}, 1 \mathrm{H}), 2.46$ (br, $6 \mathrm{H}), 2.45$ (s, 3H), 2.39 (s, 3H); ${ }^{19} \mathrm{~F}$ NMR (470 MHz, $\mathrm{CD}_{2} \mathrm{Cl}_{2}, 298$ K) $\delta-61.36\left(\mathrm{~s}, \mathrm{CF}_{3}\right)$. Anal. Calcd for $\mathrm{C}_{19} \mathrm{H}_{21} \mathrm{ClF}_{3} \mathrm{~N}_{7} \mathrm{Pt}$ : C,35.94; H, 3.33; N, 15.44. Found: C, 35.77; H, 3.60; N, 15.31.

Synthesis of [Pt(fppz)(dbpzH)Cl] (5a,b). [Pt(fppzH)Cl $\left.)_{2}\right](200$ $\mathrm{mg}, 0.43 \mathrm{mmol}$ ) and 3,5-di-tert-butylpyrazole (dbpzH, $188 \mathrm{mg}, 1.0$ mmol) in $25 \mathrm{~mL}$ of $\mathrm{CH}_{2} \mathrm{Cl}_{2}$ was stirred at room temperature for 12 $\mathrm{h}$. Then the solution was washed with deionized water and concentrated to dryness under reduced pressure. Separation of isomers was achieved by silica gel thin layer chromatography eluting with pure $\mathrm{CH}_{2} \mathrm{Cl}_{2}$. Pale yellow crystals of cis-[Pt(fppz)$(\mathrm{dbpzH}) \mathrm{Cl}](\mathbf{5 a}, 112 \mathrm{mg}, 0.18 \mathrm{mmol}, 43 \%)$ were obtained from vapor diffusion of pentane into the THF solution, while trans-[Pt$(\mathrm{fppz})(\mathrm{dbpzH}) \mathrm{Cl}] \quad(\mathbf{5 b}, \quad 80 \quad \mathrm{mg}, \quad 0.13 \quad \mathrm{mmol}, \quad 31 \%)$ was recrystallized from a mixed solution of $\mathrm{CH}_{2} \mathrm{Cl}_{2}$ and hexane at RT.

Spectral data for 5a: MS (FAB, $\left.{ }^{195} \mathrm{Pt}\right) \mathrm{m} / \mathrm{z}, 623\left(\mathrm{M}^{+}\right), 587\left(\mathrm{M}^{+}\right.$ - $\mathrm{HCl}) ;{ }^{1} \mathrm{H}$ NMR (400 MHz, $\left.\mathrm{CD}_{2} \mathrm{Cl}_{2}, 298 \mathrm{~K}\right) \delta 11.47(\mathrm{br}, 1 \mathrm{H})$, $9.12\left(\mathrm{~d}, J_{\mathrm{HH}}=6.0 \mathrm{~Hz}, 1 \mathrm{H}\right), 7.72\left(\mathrm{dd}, J_{\mathrm{HH}}=8.3,7.6 \mathrm{~Hz}, 1 \mathrm{H}\right), 7.29$ $\left(\mathrm{d}, J_{\mathrm{HH}}=8.3 \mathrm{~Hz}, 1 \mathrm{H}\right), 6.95\left(\mathrm{dd}, J_{\mathrm{HH}}=7.6,6.0 \mathrm{~Hz}, 1 \mathrm{H}\right), 6.61(\mathrm{~s}$, $1 \mathrm{H}), 6.16\left(\mathrm{~d}, J_{\mathrm{HH}}=2.8 \mathrm{~Hz}, 1 \mathrm{H}\right), 1.54(\mathrm{~s}, 9 \mathrm{H}), 1.34(\mathrm{~s}, 9 \mathrm{H}) ;{ }^{19} \mathrm{~F}$ NMR $\left(470 \mathrm{MHz}\right.$, acetone- $\left.d_{6}, 298 \mathrm{~K}\right) \delta-61.18\left(\mathrm{~s}, \mathrm{CF}_{3}\right)$. Anal. Calcd for $\mathrm{C}_{20} \mathrm{H}_{25} \mathrm{ClF}_{3} \mathrm{~N}_{5} \mathrm{Pt}$ : C, 38.56; H, 4.04; N, 11.24. Found: C, 38.27; $\mathrm{H}, 4.35 ; \mathrm{N}, 10.84$.

Spectral data for $\mathbf{5 b}:$ MS (FAB, $\left.{ }^{195} \mathrm{Pt}\right) \mathrm{m} / z 624\left(\mathrm{M}^{+}+1\right), 623$ $\left(\mathrm{M}^{+}\right), 587\left(\mathrm{M}^{+}-\mathrm{HCl}\right) ;{ }^{1} \mathrm{H} \mathrm{NMR}\left(400 \mathrm{MHz}, \mathrm{CD}_{2} \mathrm{Cl}_{2}, 298 \mathrm{~K}\right) \delta$ 12.39 (br, 1H), $7.77\left(\mathrm{dd}, J_{\mathrm{HH}}=8.2,7.3 \mathrm{~Hz}, 1 \mathrm{H}\right), 7.15\left(\mathrm{~d}, J_{\mathrm{HH}}=\right.$
$8.2 \mathrm{~Hz}, 1 \mathrm{H}), 6.82\left(\mathrm{dd}, J_{\mathrm{HH}}=7.3,5.8 \mathrm{~Hz}, 1 \mathrm{H}\right), 6.76\left(\mathrm{~d}, J_{\mathrm{HH}}=5.8\right.$ $\mathrm{Hz}, 1 \mathrm{H}), 6.16\left(\mathrm{~d}, J_{\mathrm{HH}}=2.8 \mathrm{~Hz}, 1 \mathrm{H}\right), 6.00(\mathrm{~s}, 1 \mathrm{H}), 1.54(\mathrm{~s}, 9 \mathrm{H})$, $1.50(\mathrm{~s}, 9 \mathrm{H}) ;{ }^{19} \mathrm{~F}$ NMR $\left(470 \mathrm{MHz}\right.$, acetone- $\left.d_{6}, 298 \mathrm{~K}\right) \delta-60.42$ (s, $\mathrm{CF}_{3}$ ). Anal. Calcd for $\mathrm{C}_{20} \mathrm{H}_{25} \mathrm{ClF}_{3} \mathrm{~N}_{5} \mathrm{Pt}: \mathrm{C}, 38.56 ; \mathrm{H}, 4.04 ; \mathrm{N}$, 11.24. Found: C, 38.39; H, 4.30; N, 11.13.

Synthesis of $[\mathbf{P t}(\mathbf{f p p z})(\mu-\mathbf{p z})]_{2}(\mathbf{6 a}, \mathbf{b}) .\left[\mathrm{Pt}(\mathrm{fppzH}) \mathrm{Cl}_{2}\right](100 \mathrm{mg}$, $0.21 \mathrm{mmol})$, pyrazole $(36 \mathrm{mg}, 0.52 \mathrm{mmol})$, and triethylamine $(1$ $\mathrm{mL}$ ) in $25 \mathrm{~mL}$ of $\mathrm{CH}_{2} \mathrm{Cl}_{2}$ was stirred at room temperature for $12 \mathrm{~h}$. Then the solution was washed with deionized water and concentrated to dryness under reduced pressure. Separation of isomers was achieved by silica gel thin layer chromatography eluting with $\mathrm{CH}_{2} \mathrm{Cl}_{2}$, affording pale-yellow colored trans-[Pt(fppz)(u-pz) $]_{2}(\mathbf{6} \mathbf{a}$, $22 \mathrm{mg}, 0.023 \mathrm{mmol}, 22 \%)$ and cis-[Pt(fppz)( $\mu$-pz) $]_{2}(\mathbf{6 b}, 45 \mathrm{mg}$, $0.047 \mathrm{mmol}, 45 \%)$. Crystals suitable for X-ray diffraction studies were obtained from pure $\mathrm{CH}_{2} \mathrm{Cl}_{2}$ and pure acetone solution for the trans and the cis isomer, respectively.

Spectral data for 6a: MS (FAB, $\left.{ }^{195} \mathrm{Pt}\right) \mathrm{m} / \mathrm{z} 949\left(\mathrm{M}^{+}\right) ;{ }^{1} \mathrm{H}$ NMR $\left(400 \mathrm{MHz}\right.$, acetone- $\left.d_{6}, 298 \mathrm{~K}\right) \delta 8.21\left(\mathrm{ddd}, J_{\mathrm{HH}}=7.6,7.4,1.3 \mathrm{~Hz}\right.$, $2 \mathrm{H}), 8.13\left(\mathrm{~d}, J_{\mathrm{HH}}=6.0 \mathrm{~Hz}, 2 \mathrm{H}\right), 8.06\left(\mathrm{~d}, J_{\mathrm{HH}}=7.4 \mathrm{~Hz}, 2 \mathrm{H}\right), 7.96$ $\left(\mathrm{d}, J_{\mathrm{HH}}=2.4 \mathrm{~Hz}, 2 \mathrm{H}\right), 7.82\left(\mathrm{~d}, J_{\mathrm{HH}}=2.0 \mathrm{~Hz}, 2 \mathrm{H}\right), 7.47\left(\mathrm{ddd}, J_{\mathrm{HH}}\right.$ $=7.6,6.0,1.3 \mathrm{~Hz}, 2 \mathrm{H}), 7.20(\mathrm{~s}, 2 \mathrm{H}), 6.48\left(\mathrm{dd}, J_{\mathrm{HH}}=2.4,2.0 \mathrm{~Hz}\right.$, $2 \mathrm{H}) ;{ }^{19} \mathrm{~F}$ NMR (470 MHz, acetone- $\left.d_{6}, 298 \mathrm{~K}\right) \delta-60.99\left(\mathrm{~s}, \mathrm{CF}_{3}\right)$. Anal. Calcd for $\mathrm{C}_{24} \mathrm{H}_{16} \mathrm{~F}_{6} \mathrm{~N}_{10} \mathrm{Pt}_{2}$ : C, 30.39; H, 1.70; N, 14.77. Found: C, 30.27; H, 1.86; N, 14.68.

Spectral data for $6 \mathbf{b}$ : MS (FAB, $\left.{ }^{195} \mathrm{Pt}\right) \mathrm{m} / z, 949\left(\mathrm{M}^{+}\right) ;{ }^{1} \mathrm{H}$ NMR $\left(400 \mathrm{MHz}\right.$, acetone- $\left.d_{6}, 298 \mathrm{~K}\right) \delta 8.33\left(\mathrm{~d}, J_{\mathrm{HH}}=6.0 \mathrm{~Hz}, 2 \mathrm{H}\right), 8.18$ $\left(\mathrm{dd}, J_{\mathrm{HH}}=7.8,6.2 \mathrm{~Hz}, 2 \mathrm{H}\right), 8.04\left(\mathrm{~d}, J_{\mathrm{HH}}=7.8 \mathrm{~Hz}, 2 \mathrm{H}\right), 7.95(\mathrm{~d}$, $\left.J_{\mathrm{HH}}=2.2 \mathrm{~Hz}, 2 \mathrm{H}\right), 7.86\left(\mathrm{~d}, J_{\mathrm{HH}}=2.4 \mathrm{~Hz}, 2 \mathrm{H}\right), 7.37\left(\mathrm{dd}, J_{\mathrm{HH}}=\right.$ $6.2,6.0 \mathrm{~Hz}, 2 \mathrm{H}), 7.13(\mathrm{~s}, 2 \mathrm{H}), 6.60\left(\mathrm{t}, J_{\mathrm{HH}}=2.2 \mathrm{~Hz}, 1 \mathrm{H}\right), 6.32(\mathrm{t}$, $\left.J_{\mathrm{HH}}=2.4 \mathrm{~Hz}, 1 \mathrm{H}\right) ;{ }^{19} \mathrm{~F}$ NMR $\left(470 \mathrm{MHz}\right.$, acetone- $\left.d_{6}, 298 \mathrm{~K}\right) \delta$ $-61.16\left(\mathrm{~s}, \mathrm{CF}_{3}\right)$. Anal. Calcd for $\mathrm{C}_{24} \mathrm{H}_{16} \mathrm{~F}_{6} \mathrm{~N}_{10} \mathrm{Pt}_{2}$ : C, 30.39; $\mathrm{H}$, $1.70 ; \mathrm{N}, 14.77$. Found: C, 30.22; H, 1.99; N, 14.58 .

Synthesis of $\left[\mathbf{P t}(\mathbf{f p p z})(\boldsymbol{\mu} \text {-dmpz) }]_{2}(\mathbf{7 a}, \mathbf{b}) \cdot\left[\mathrm{Pt}(\mathrm{fppzH}) \mathrm{Cl}_{2}\right](100\right.$ $\mathrm{mg}, 0.21 \mathrm{mmol}), 3,5$-dimethylpyrazole (dmpzH, $50 \mathrm{mg}, 0.52 \mathrm{mmol}$ ), and triethylamine $(1 \mathrm{~mL})$ in $25 \mathrm{~mL}$ of $\mathrm{CH}_{2} \mathrm{Cl}_{2}$ was stirred at room temperature for $12 \mathrm{~h}$. Then the solution was washed with deionized water and concentrated to dryness under reduced pressure. Separation of isomers was achieved by silica gel thin layer chromatography eluting with $\mathrm{CH}_{2} \mathrm{Cl}_{2}$. Colorless trans-[Pt(fppz) $(\mu \text {-dmpz) }]_{2}$ (7a, 30 $\mathrm{mg}, 0.03 \mathrm{mmol}, 29 \%)$ and cis-[Pt(fppz)$(\mu-\mathrm{dmpz})]_{2}(7 \mathbf{b}, 44 \mathrm{mg}$, $0.044 \mathrm{mmol}, 41 \%$ ) were obtained from recrystallization in acetone and $\mathrm{CH}_{2} \mathrm{Cl}_{2}$ solution, respectively.

Spectral data for 7a: MS (FAB, $\left.{ }^{195} \mathrm{Pt}\right) \mathrm{m} / z, 1004\left(\mathrm{M}^{+}\right) ;{ }^{1} \mathrm{H}$ NMR $\left(400 \mathrm{MHz}\right.$, acetone- $\left.d_{6}, 298 \mathrm{~K}\right) \delta 8.13\left(\mathrm{dd}, J_{\mathrm{HH}}=8.2,6.8 \mathrm{~Hz}, 2 \mathrm{H}\right)$, $8.05\left(\mathrm{~d}, J_{\mathrm{HH}}=6.0 \mathrm{~Hz}, 2 \mathrm{H}\right), 7.95\left(\mathrm{~d}, J_{\mathrm{HH}}=8.2 \mathrm{~Hz}, 2 \mathrm{H}\right), 7.39(\mathrm{dd}$, $\left.J_{\mathrm{HH}}=6.8,6.0 \mathrm{~Hz}, 2 \mathrm{H}\right), 7.06(\mathrm{~s}, 2 \mathrm{H}), 6.00(\mathrm{~s}, 2 \mathrm{H}), 2.42(\mathrm{~s}, 6 \mathrm{H})$, $2.32(\mathrm{~s}, 6 \mathrm{H}) ;{ }^{19} \mathrm{~F}$ NMR $\left(470 \mathrm{MHz}\right.$, acetone- $\left.d_{6}, 298 \mathrm{~K}\right) \delta-61.07$ (s, $\mathrm{CF}_{3}$ ). Anal. Calcd for $\mathrm{C}_{28} \mathrm{H}_{24} \mathrm{~F}_{6} \mathrm{~N}_{10} \mathrm{Pt}_{2}: \mathrm{C}, 33.47 ; \mathrm{H}, 2.41 ; \mathrm{N}$, 13.94. Found: C, 33.31; H, 2.58; N, 14.13.

Spectral data for 7b: ${ }^{1} \mathrm{H}$ NMR (400 MHz, DMSO- $\left.d_{6}, 298 \mathrm{~K}\right) \delta$ $8.17\left(\mathrm{dd}, J_{\mathrm{HH}}=7.8,7.0 \mathrm{~Hz}, 2 \mathrm{H}\right), 8.09\left(\mathrm{~d}, J_{\mathrm{HH}}=6.2 \mathrm{~Hz}, 2 \mathrm{H}\right), 8.06$ $\left(\mathrm{d}, J_{\mathrm{HH}}=7.8 \mathrm{~Hz}, 2 \mathrm{H}\right), 7.35\left(\mathrm{dd}, J_{\mathrm{HH}}=7.0,6.2 \mathrm{~Hz}, 2 \mathrm{H}\right), 7.28(\mathrm{~s}$, $2 \mathrm{H}), 6.19(\mathrm{~s}, 1 \mathrm{H}), 5.91(\mathrm{~s}, 1 \mathrm{H}), 2.27(\mathrm{br}, 12 \mathrm{H}) ;{ }^{19} \mathrm{~F}$ NMR (470 $\left.\mathrm{MHz}, \mathrm{DMSO}-d_{6}, 298 \mathrm{~K}\right) \delta-59.14\left(\mathrm{~s}, \mathrm{CF}_{3}\right)$. Anal. Calcd for $\mathrm{C}_{28} \mathrm{H}_{24} \mathrm{~F}_{6} \mathrm{~N}_{10} \mathrm{Pt}_{2}$ : C, 33.47; H, 2.41; N, 13.94. Found: C, 33.29; H, $2.61 ; \mathrm{N}, 14.10$.

Spectroscopic and Dynamic Measurements. Steady-state absorption and emission spectra were recorded on a Hitachi (U3310) spectrophotometer and an Edinburgh (FS920) fluorometer, respectively. Both wavelength-dependent excitation and emission response of the fluorometer have been calibrated. A configuration of front-face excitation was used to measure the emission of the solid sample, in which the cell was made 


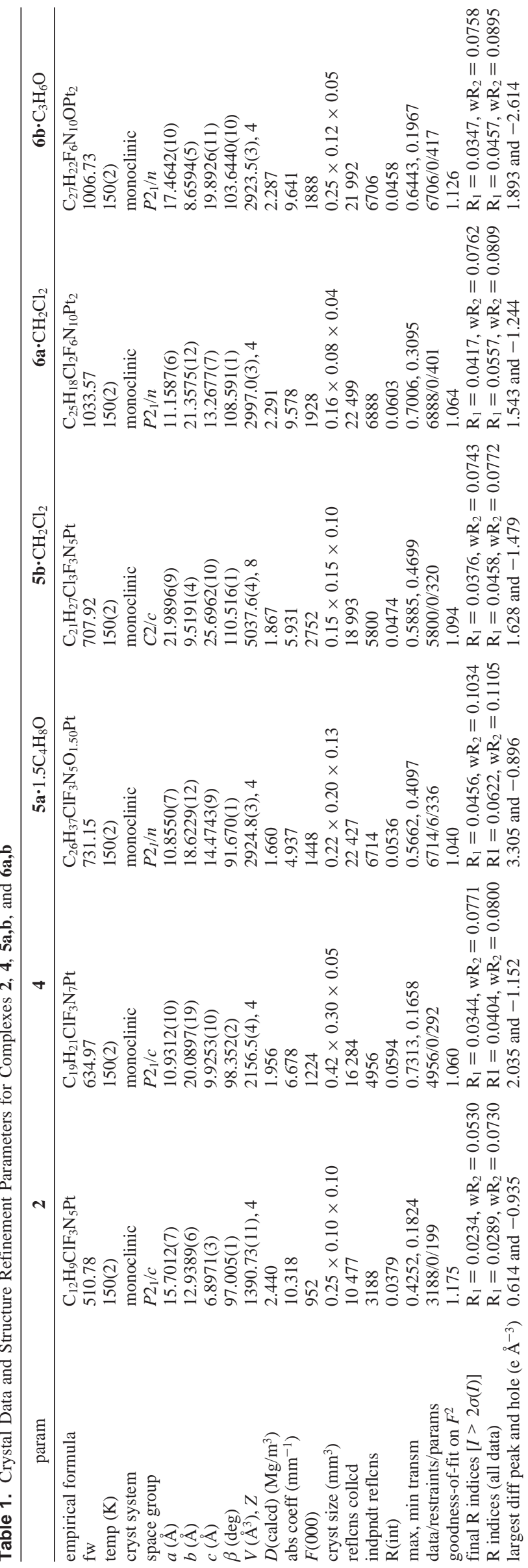

by assembling two edge-polished quartz plates with various Teflon spacers. A combination of appropriate filters was used to avoid interference from the scattering light. Lifetime studies were performed by an Edinburgh FL 900 photon-counting system with a hydrogen-filled/or a nitrogen lamp as the excitation source. Data were analyzed using a nonlinear least-squares procedure in combination with an iterative convolution method. The emission decays were analyzed by the sum of exponential functions, which allows partial removal of the instrument time broadening and consequently renders a temporal resolution of $\sim 200$ ps.

To determine the photoluminescence quantum yield in solution, samples were degassed by three freeze-pump-thaw cycles under vigorous stirring conditions. Quinine sulfate with an emission yield of $\Phi \sim 0.54 \pm 0.2$ in $1.0 \mathrm{~N}$ sulfuric acid solution served as the standard to calculate the emission quantum yield. An integrating sphere (Labsphere) was applied to measure the quantum yield in the solid state, for which the solid thin film was prepared via direct vacuum deposition and was excited by argon ion laser at $\sim 363$ $\mathrm{nm}$. The resulting luminescence was acquired with an intensified charge-coupled detector for subsequent quantum yield analyses according to a reported method. ${ }^{8}$

X-ray Structural Analysis. All single-crystal X-ray diffraction data were measured on a Bruker Smart CCD diffractometer using Mo K radiation $(\lambda=0.71073 \AA)$. The data collection was executed using the SMART program. Cell refinement and data reduction were made with the SAINT program. The structure was determined using the SHELXTL/PC program and refined using full-matrix least squares. All non-hydrogen atoms were refined anisotropically, whereas hydrogen atoms were placed at the calculated positions and included in the final stage of refinements with fixed parameters. The respective crystallographic refinement parameters are summarized in Table 1.

Theoretical Approaches. Calculations on the electronic ground state of complexes $\mathbf{4}$ and $\mathbf{7 a}, \mathbf{b}$ were carried out by using B3LYP density functional theory. ${ }^{9}$ A "double- $\zeta$ " quality basis set consisting of the Hay and Wadt effective core potentials (LANL2DZ) ${ }^{10}$ was employed for the $\mathrm{Pt}(\mathrm{II})$ atoms, and a $6-31 \mathrm{G}^{*}$ basis, ${ }^{11}$ for $\mathrm{H}, \mathrm{C}$, $\mathrm{N}$, and $\mathrm{F}$ atoms. Time-dependent DFT (TDDFT) calculations by using the B3LYP functional were then performed on the basis of the geometry-optimized structures. Oscillator strengths $(f)$ were deduced from the dipole transition matrix elements (for the singlet states only). The ground-state B3LYP and excited-state TDDFT calculations were carried out by using Gaussian 03. ${ }^{12}$ In the frontier region, neighboring orbitals are often closely spaced. In such cases, consideration of only the HOMO and LUMO may not yield a realistic description. For this reason, partial density of states (PDOS) diagrams, which incorporate a degree of overlap between the curves convoluted from neighboring energy levels, can give a more representative picture. The contribution of a group to a specific molecular orbital was calculated within the framework of Mulliken population analyses. The PDOS spectra were then created by convoluting the molecular orbital infor-

(8) de Mello, J. C.; Wittmann, H. F.; Friend, R. H. Adv. Mater. 1997, 9, 230.

(9) (a) Becke, A. D. Phys. Rev. A 1988, 38, 3098. (b) Lee, C.; Yang, W.; Parr, R. G. Phys. Rev. B 1988, 37, 785. (c) Miehlich, B.; Savin, A.; Stoll, H.; Preuss, H. Chem. Phys. Lett. 1989, 157, 200.

(10) (a) Hay, P. J.; Wadt, W. R. J. Chem. Phys. 1985, 82, 270. (b) Wadt, W. R.; Hay, P. J. J. Chem. Phys. 1985, 82, 284. (c) Hay, P. J.; Wadt, W. R. J. Chem. Phys. 1985, 82, 299.

(11) Hariharan, P. C.; Pople, J. A. Mol. Phys. 1974, 27, 209.

(12) Gaussian 03, revision C.02; Gaussian, Inc.: Wallingford, CT, 2004.

Inorganic Chemistry, Vol. 46, No. 26, 200711205 


\section{Chang et al.}

mation with Gaussian curves of unit height and fwhm of $0.5 \mathrm{eV}$. The PDOS diagrams for $\mathbf{7 a}, \mathbf{b}$, shown in this work, are generated using the AOMix program. ${ }^{13}$

\section{Results and Discussion}

Synthesis and Characterization. By adoption of the synthetic protocols reported for the $\mathrm{Pt}(\mathrm{II})$ diimine complex such as $\left[\mathrm{Pt}(\mathrm{bpy}) \mathrm{Cl}_{2}\right],{ }^{14}$ treatment of 1 equiv of $\mathrm{fppzH}$ with $\mathrm{K}_{2} \mathrm{PtCl}_{4}$ in $\mathrm{HCl}$ solution yielded neutral, chloride-substituted complex [Pt(fppzH)Cl $\mathrm{Cl}_{2}$ (1) in high yield, together with a trace amount of orange-emitting $\left[\mathrm{Pt}(\mathrm{fppz})_{2}\right]$. According to our previous observation, it is possible that complex $\mathbf{1}$ is the intermediate en route to the formation of $\left[\mathrm{Pt}(\mathrm{fppz})_{2}\right]$, which involves the addition of a second fppzH ligand with simultaneous elimination of 2 equiv of $\mathrm{HCl}$. Moreover, the addition of excessive $\mathrm{HCl}$ is to provide a dual function, namely to block the proton dissociation from the fppzH chelate as well as to retard the chloride dissociation from $\mathbf{1}$, such that the formation of $\left[\mathrm{Pt}(\mathrm{fppz})_{2}\right]$ can be effectively suppressed.
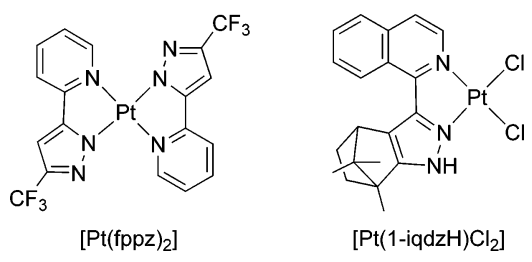

In view of physical properties, complex 1 imparts high solubility in most common organic solvents such as acetone and THF, except chlorinated solvents such as $\mathrm{CH}_{2} \mathrm{Cl}_{2}$ and hydrocarbons. One key feature was revealed by the observation of five ${ }^{1} \mathrm{H}$ NMR signals in the region $\delta 9.45-7.77$ with equal intensities, corresponding to the aromatic proton signals of fppzH chelate. However, the unique NH signal was not observed under this condition, which is apparently due to its high acidity exerted by the electron-withdrawing nature of the pyrazole ligand and the associated $\mathrm{CF}_{3}$ substituent. Such behavior differs from that that of the previously reported $\mathrm{Pt}(\mathrm{II})$ metal complex $\left[\mathrm{Pt}(1\right.$-iqdzH $\left.) \mathrm{Cl}_{2}\right]$, iqdzH = 1 -isoquinolinyl indazole, for which its solid-state structure was established by single-crystal X-ray structural analyses. ${ }^{15}$ Moreover, successful isolation of $\mathbf{1}$ further confirms that this class of pyridyl pyrazole ligand, despite of its higher acidity, can act as a neutral chelate in assembling various metal complexes. ${ }^{16}$

After confirming the identity of $\mathbf{1}$, we then proceeded to investigate the chemical reactivity associated with this new $\mathrm{Pt}(\mathrm{II})$ starting material. The first reaction is the treatment

(13) (a) Gorelsky, S. I.; Lever, A. B. P. J. Organomet. Chem. 2001, 635, 187. (b) Gorelsky, S. I. AOMix, revision 6.33; http://www.sg-chem. net/.

(14) (a) Osborn, R. J.; Rogers, D. J. Chem. Soc., Dalton Trans. 1974, 1002. (b) Egan, T. J.; Koch, K. R.; Swan, P. L.; Clarkson, C.; Van Schalkwyk, D. A.; Smith, P. J. J. Med. Chem. 2004, 47, 2926.

(15) Chang, S. Y.; Kavitha, J.; Hung, J. Y.; Chi, Y.; Cheng, Y. M.; Li, E. Y.; Chou, P. T.; Lee, G. H.; Carty, A. J. Inorg. Chem. 2007, 46, 7064.

(16) (a) Vos, J. G.; Kelly, J. M. Dalton Trans. 2006, 4869. (b) Browne, W. R.; O’Boyle, N. M.; McGarvey, J. J.; Vos, J. G. Chem. Soc. Rev. 2005, 34, 641. (c) Koo, C. K.; Lam, B.; Leung, S. K.; Lam, M. H. W.; Wong, W. Y. J. Am. Chem. Soc. 2006, 128, 16434. with an excess of pyrazole (pzH), at RT, which afforded a single substitution product of formula $[\mathrm{Pt}(\mathrm{fppz})(\mathrm{pzH}) \mathrm{Cl}]$ (2) in high yield. Its identification was initially revealed by the routine ${ }^{1} \mathrm{H}$ NMR analysis, showing a total of eight aromatic proton signals due to the coexistence of one fppz and one pzH ligand, together with a downfield signal at $\delta 15.29$ due to the $\mathrm{NH}$ group that showed H-bonding. Moreover, the reaction of $\mathbf{1}$ with 3,5-dimethylpyrazole gave a mixture of two mononuclear $\mathrm{Pt}(\mathrm{II})$ complexes [Pt$(\mathrm{fppz})(\mathrm{dmpzH}) \mathrm{Cl}](\mathbf{3})$ and $\left[\mathrm{Pt}(\mathrm{fppz})(\mathrm{dmpzH})_{2}\right] \mathrm{Cl}(\mathbf{4})$. Complex $\mathbf{3}$ is akin to the previously mentioned pyrazole analogue 2 with only one dmpz ligand, while complex 4 shows the existence of two monodentate dmpzH fragments, instead of the possession of a planar $(\mathrm{dmpz})_{2} \mathrm{H}$ chelate, the configuration of which is similar to the $\left(\mathrm{pz}_{2}\right) \mathrm{H}$ chelate previously observed in the octahedral $\operatorname{Ir}(\mathrm{III})$ pyrazole derivatives. ${ }^{17}$ Naturally, the greater electron-donating character of dmpzH versus that of pzH ligand makes it more feasible to coordinate with the $\mathrm{Pt}(\mathrm{II})$ center without the concomitant dissociation of proton. In sharp contrast, reaction of $\mathbf{1}$ with 3,5-di-tert-butylpyrazole, dbpzH, led to the formation of two yellow complexes, denoted as $\mathbf{5 a}, \mathbf{b}$, which could be isolated after a simple separation using silica gel thin-layer chromatography in $43 \%$ and $31 \%$ yields, respectively. Spectroscopic investigation on $\mathbf{5 a}, \mathbf{b}$ revealed their isomeric nature, as their ${ }^{1} \mathrm{H}$ NMR spectra exhibited all of the signals derived from fppz chelate and dbpzH ligand, as well as one slightly less downfield NH resonance signal: $\mathbf{5 a}, \delta$ 11.47, and $\mathbf{5 b}, \delta$ 12.39 , in $\mathrm{CD}_{2} \mathrm{Cl}_{2}$ solution.

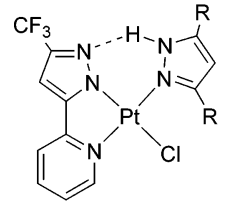

(2) $\mathrm{R}=\mathrm{H}$; (3) $\mathrm{R}=\mathrm{Me}$

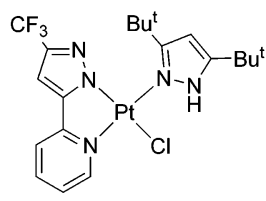

(5a)

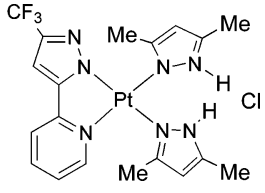

(4)

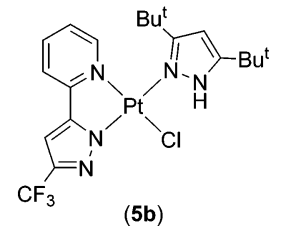

(5b)
Single-crystal X-ray analysis on $\mathbf{2}$ was undertaken for revealing the salient structural features. An ORTEP drawing and its one-dimensional stacking diagram in the crystal lattices are depicted in Figure 1. As expected, the Pt(II) metal reveals an essential square-planar coordination geometry. The acidic proton on pyrazole forms nonbonding contact with the adjacent $\mathrm{N}(1)$ atom of the fppz chelate $(\mathrm{N}(5) \cdots \mathrm{H}(2 \mathrm{~A})=$ 1.968(2) $\AA$ ), while the $\mathrm{Pt}-\mathrm{N}(4)$ distance of the fppz chelate (1.986(4) $\AA$ ) is slightly shorter than that of its pyridyl counterpart $(\mathrm{Pt}-\mathrm{N}(3)=2.024(4) \AA)$ and the monodentate pyrazole $(\mathrm{Pt}-\mathrm{N}(1)=2.012(5) \AA)$. This variation of $\mathrm{Pt}-\mathrm{N}$ bond distances could be due to the anionic nature of the fppz

(17) Li, J.; Djurovich, P. I.; Alleyne, B. D.; Tsyba, I.; Ho, N. N.; Bau, R.; Thompson, M. E. Polyhedron 2004, 23, 419. 


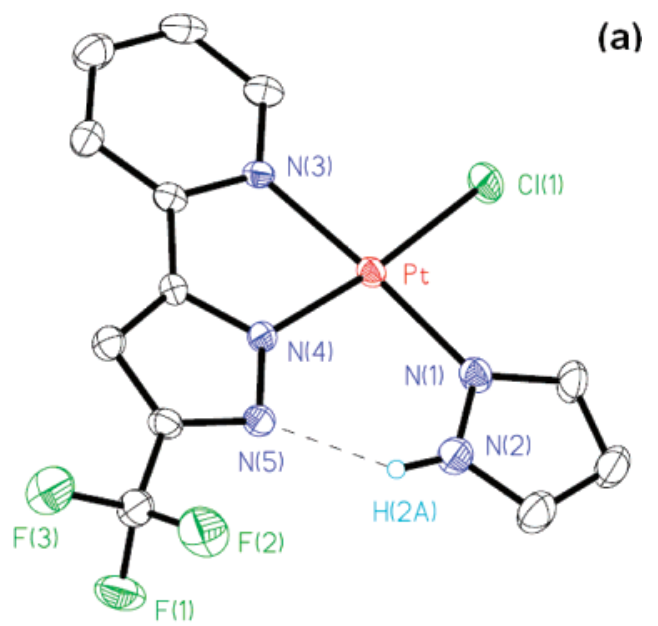

(b)

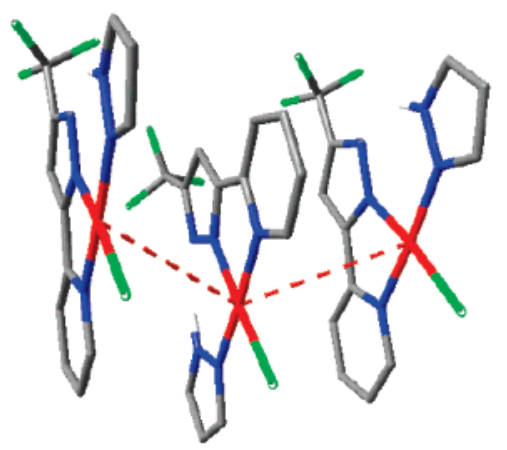

Figure 1. (a) ORTEP diagram of $\mathbf{2}$ with thermal ellipsoids shown at $50 \%$ probability level. Selected bond distances: $\mathrm{Pt}-\mathrm{N}(1)=2.012(5), \mathrm{Pt}-\mathrm{N}(3)$ $=2.024(4), \mathrm{Pt}-\mathrm{N}(4)=1.986(4), \mathrm{Pt}-\mathrm{Cl}(1)=2.2983(14), \mathrm{N}(5) \cdots \mathrm{H}(2 \mathrm{~A})$ $=1.968 \AA$. (b) Stacking diagram showing the shortest $\mathrm{Pt}-\mathrm{Pt}$ interaction.

ligand, which offered a stronger dative interaction between pyrazolate and $\mathrm{Pt}(\mathrm{II})$ cation through enhanced Coulomb attraction. Moreover, the intermolecular Pt...Pt contact between each $\mathrm{Pt}(\mathrm{II})$ molecule is calculated to be 4.050(1) $\AA$, which is significantly longer than those $(3.0-3.5 \AA)$ reported for the columnar stacked $\left[\mathrm{Pt}(\mathrm{bpy}) \mathrm{Cl}_{2}\right]$ or $[\mathrm{Pt}$ $\left.(\text { diimine })_{2}(\mathrm{CN})_{2}\right]$, diimine $=$ bipyridine and biisoquinoline, ${ }^{18}$ and even the infinite linear stacks of the nanowires $\left[\mathrm{Pt}\left(\mathrm{CN}^{\mathrm{t}}-\right.\right.$ $\left.\mathrm{Bu})_{2}(\mathrm{CN})_{2}\right](3.354(1) \AA),{ }^{19}$ indicating no significant $\mathrm{Pt}-\mathrm{Pt}$ interaction between each individual molecule.

The molecular structure of $\mathbf{4}$ was determined by X-ray crystallography, and its ORTEP diagram is depicted in Figure 2. In contrast to the previously discussed complex $\mathbf{2}$ possessing only one neutral pyrazole ligand, the $\mathrm{Pt}$ atom in 4 is simultaneously coordinated by two neutral dmpzH ligands that are essentially perpendicular to each other, giving a cationic entity. The associated positive charge is then balanced by the free chloride ion, which forms a strong bonding interaction with the $\mathrm{N}-\mathrm{H}$ fragment of the dmpzH ligands.

(18) (a) Che, C. M.; He, L. Y.; Poon, C. K.; Mak, T. C. W. Inorg. Chem. 1989, 28, 3081. (b) Kato, M.; Sasano, K.; Kosuge, C.; Yamazaki, M.; Yano, S.; Kimura, M. Inorg. Chem. 1996, 35, 116. (c) Kato, M.; Kosuge, C.; Morii, K.; Ahn, J. S.; Kitagawa, H.; Mitani, T.; Matsushita, M.; Kato, T.; Yano, S.; Kimura, M. Inorg. Chem. 1999, 38, 1638. (d) Connick, W. B.; Henling, L. M.; Marsh, R. E.; Gray, H. B. Inorg. Chem. 1996, 35, 6261. (e) Connick, W. B.; Marsh, R. E.; Schaefer, W. P.; Gray, H. B. Inorg. Chem. 1997, 36, 913.

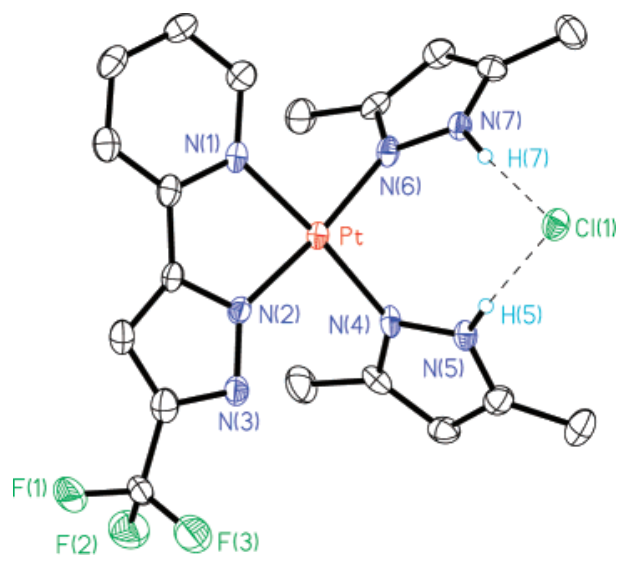

Figure 2. ORTEP diagram of $\mathbf{4}$ with thermal ellipsoids shown at $50 \%$ probability level. Selected bond distances: $\mathrm{Pt}-\mathrm{N}(2)=1.970(4), \mathrm{Pt}-\mathrm{N}(4)$ $=2.005(4), \mathrm{Pt}-\mathrm{N}(6)=2.010(4), \mathrm{Pt}-\mathrm{N}(1)=2.023(4), \mathrm{Cl}(1) \cdots \mathrm{H}(5)=$ $2.252, \mathrm{Cl}(1) \cdots \mathrm{H}(7)=2.127 \AA$.

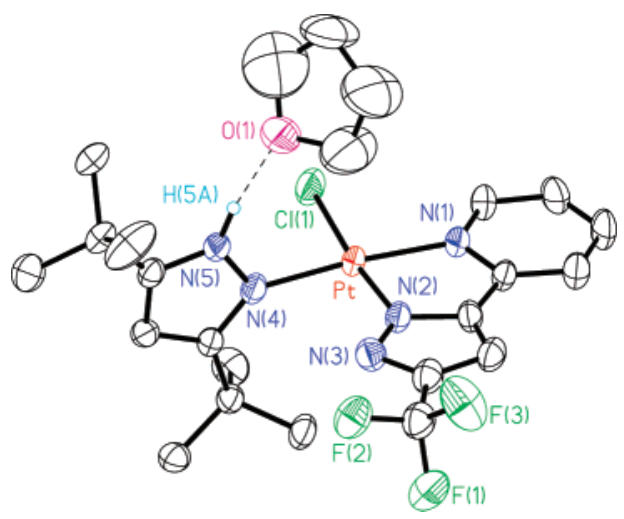

Figure 3. ORTEP diagram of 5a with thermal ellipsoids shown at 50\% probability level. Selected metrics: bond distances, $\mathrm{Pt}-\mathrm{Cl}(1)=2.295(2)$, $\mathrm{Pt}-\mathrm{N}(1)=2.022(5), \mathrm{Pt}-\mathrm{N}(2)=1.980(5), \mathrm{Pt}-\mathrm{N}(4)=2.005(5), \mathrm{O}(1) \cdots$ $\mathrm{H}(5 \mathrm{~A})=1.896 \AA$; bond angles, $\mathrm{N}(1)-\mathrm{Pt}-\mathrm{N}(4)=174.5(2), \mathrm{Cl}(1)-\mathrm{Pt}-$ $\mathrm{N}(2)=173.91(14), \mathrm{Cl}(1)-\mathrm{Pt}-\mathrm{N}(4)=89.78(15), \mathrm{N}(1)-\mathrm{Pt}-\mathrm{N}(2)=80.2(2)$ deg.

As for the dbpzH adduct, complex 5a shows incorporation of 1.5 equiv of THF solvate molecules (Figure 3), while the $\mathrm{Pt}(\mathrm{II})$ coordination geometry is identical with that of $\mathbf{2}$, showing the expected cis arrangement between pyridyl and chloride ligands, except that the monodentate dbpzH ligand is now rotated by $90^{\circ}$ along the $\mathrm{Pt}-\mathrm{N}$ bond and becomes perpendicular to the chelating fppz ligand. Interestingly, the crystal packing diagram shows formation of one novel $\mathrm{N}-\mathrm{H} \cdot$ -OO interaction to the adjacent THF solvate, which substitutes the interligand $\mathrm{H}$-bonding observed in $\mathbf{2}$.

On the other hand, a crystal of $\mathbf{5 b}$ exhibits a weakly stacked dimeric unit in the solid state (Figure 4). The dbpzH ligand is located trans to the pyrazolate anion of the fppz chelate, the orientation of which is different from the cisconfiguration shown by $\mathbf{2}$, confirming the coexistence of geometrical isomerism. Again, the dbpzH unit, probably attributed to its bulky tert-butyl group, turns perpendicular with respect to the square planar coordination framework.

(19) Sun, Y.; Ye, K.; Zhang, H.; Zhang, J.; Zhao, L.; Li, B.; Yang, G.; Yang, B.; Wang, Y.; Lai, S. W.; Che, C. M. Angew. Chem., Int. Ed. 2006, 45,5610 . 


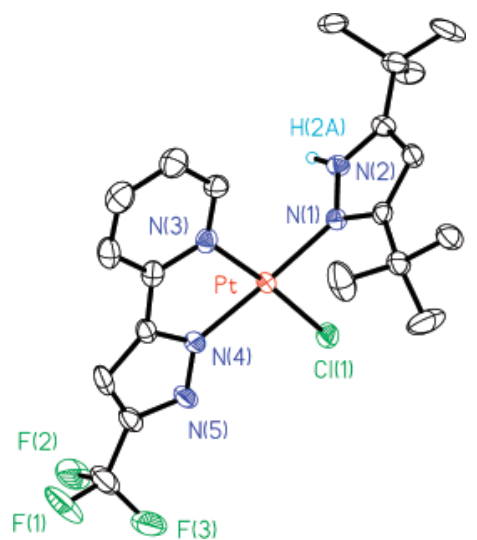

Figure 4. ORTEP diagram of $\mathbf{5 b}$ with thermal ellipsoids shown at $50 \%$ probability level. Selected metrics: bond distances, $\mathrm{Pt}-\mathrm{Cl}(1)=2.2889$ (12), $\mathrm{Pt}-\mathrm{N}(1)=2.025(4), \mathrm{Pt}-\mathrm{N}(3)=2.024(4), \mathrm{Pt}-\mathrm{N}(4)=1.970(4) \AA$ bond angles, $\mathrm{N}(1)-\mathrm{Pt}-\mathrm{N}(4)=173.10(16), \mathrm{Cl}(1)-\mathrm{Pt}-\mathrm{N}(3)=175.52(12)$, $\mathrm{Cl}(1)-\mathrm{Pt}-\mathrm{N}(1)=90.45(12), \mathrm{N}(3)-\mathrm{Pt}-\mathrm{N}(4)=79.96(17) \mathrm{deg}$.

As a consequence, the acidic $\mathrm{NH}$ functional group is now pointed toward the nitrogen lone pair of fppz ligand as well as the chloride ion of the adjacent Pt(II) molecule; cf. N(5)• $\cdot \cdot \mathrm{H}(2 \mathrm{~A})=2.742(2)$ and $\mathrm{Cl}(1) \cdots \mathrm{H}(2 \mathrm{~A})=2.511(2) \AA$. Of particular interest is the $\mathrm{Cl}-\mathrm{H}$ nonbonding contact, which is shorter than the sum $(2.95 \AA)$ of the van der Waals radii of hydrogen and chlorine, ${ }^{20}$ showing a stronger H-bonding interaction. Moreover, the intermolecular Pt $\cdots$ Pt separation of $3.550 \AA$, which is notably shorter than that of $\mathbf{2}$ but is comparable to those reported for $\left[(\text { tpy })_{2} \mathrm{Pt}_{2}(\mu-\mathrm{pz})\right]^{3+}(3.432$ $\AA$ ) and related diphosphine-bridged derivatives, confirming the formation of dimeric stacking units. ${ }^{21}$

Blue-Emitting Pt(II) Dimers. The dinuclear pyrazolatebridge complexes $[\mathrm{Pt}(\mathrm{fppz})(\boldsymbol{\mu}-\mathrm{pz})]_{2}(\mathbf{6} \mathbf{6}, \mathbf{b})$ are obtained in a single step by treatment of $\mathbf{2}$ with excess of $\mathrm{NEt}_{3}$ or, alternatively, by treatment of $\mathbf{1}$ in $\mathrm{CH}_{2} \mathrm{Cl}_{2}$ with an excess of pyrazole reagent in presence of $\mathrm{NEt}_{3}$, which acts as the proton or acid scavenger. The second approach is particularly useful for preparation of the related 3,5-dimethylpyrazolate-bridged complexes $[\mathrm{Pt}(\mathrm{fppz})(\mu-\mathrm{dmpz})]_{2}(\mathbf{7 a}, \mathbf{b})$ simply because that the possible reaction intermediate $\mathbf{3}$ was isolated in relatively much lower yield versus that of $\mathbf{2}$.

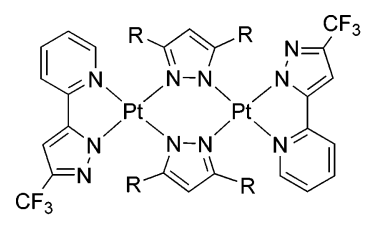

(6a) $\mathrm{R}=\mathrm{H} ;(\mathbf{7 a}) \mathrm{R}=\mathrm{Me}$

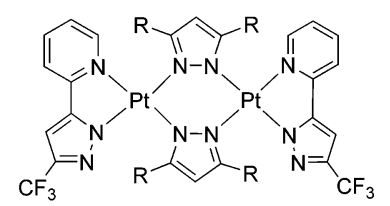

(6b) $\mathrm{R}=\mathrm{H}$; (7b) $\mathrm{R}=\mathrm{Me}$
Molecular structures of $\mathbf{6 a}, \mathbf{b}$ were also confirmed by X-ray diffraction. As shown in Figures 5 and 6, both complexes consist of two $\mathrm{Pt}(\mathrm{fppz})$ fragments with a configuration resembling wings of butterfly, which are then linked one another through two bridging pyrazolate ligands. The in-

(20) (a) Brammer, L.; Bruton, E. A.; Sherwood, P. Cryst. Growth Des. 2001, 1, 277. (b) Thallapally, P. K.; Nangia, A. CrystEngComm 2001, $27,1$.

(21) (a) Bailey, J. A.; Miskowski, V. M.; Gray, H. B. Inorg. Chem. 1993 , 32, 369. (b) Lai, S. W.; Chan, M. C. W.; Cheung, T. C.; Peng, S. M.; Che, C. M. Inorg. Chem. 1999, 38, 4046.

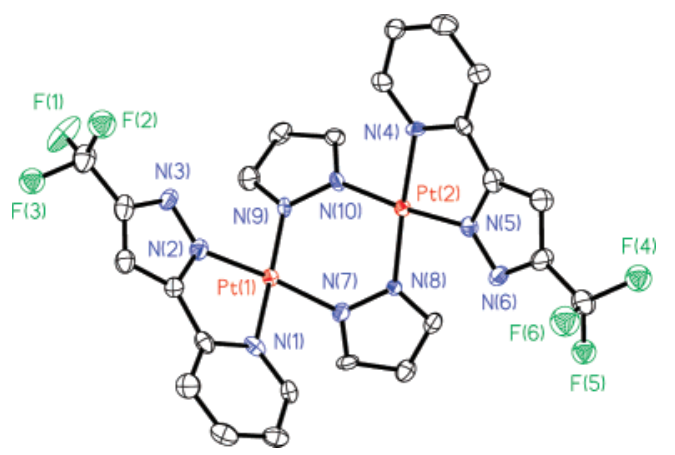

Figure 5. ORTEP diagram of 6a with thermal ellipsoids shown at 50\% probability level. Selected bond distances: $\mathrm{Pt}(1)-\mathrm{N}(1)=2.030(6), \mathrm{Pt}(1)-$ $\mathrm{N}(2)=1.985(6), \operatorname{Pt}(1)-\mathrm{N}(7)=2.013(6), \mathrm{Pt}(1)-\mathrm{N}(9)=1.983(6), \mathrm{Pt}(2)-$ $\mathrm{N}(4)=2.034(5), \operatorname{Pt}(2)-\mathrm{N}(5)=1.986(5), \operatorname{Pt}(2)-\mathrm{N}(8)=1.988(5), \operatorname{Pt}(2)-$ $\mathrm{N}(10)=2.013(6), \operatorname{Pt}(1) \cdots \operatorname{Pt}(2)=3.437(1) \AA$.

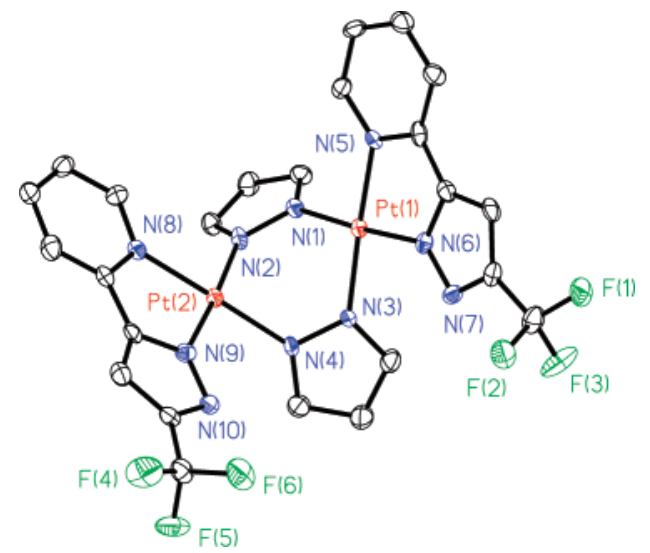

Figure 6. ORTEP diagram of $\mathbf{6 b}$ with thermal ellipsoids shown at $50 \%$ probability level. Selected bond distances: $\operatorname{Pt}(1)-\mathrm{N}(1)=2.023(5), \operatorname{Pt}(1)-$ $\mathrm{N}(3)=1.995(5), \operatorname{Pt}(1)-\mathrm{N}(5)=2.015(5), \mathrm{Pt}(1)-\mathrm{N}(6)=1.980(5), \mathrm{Pt}(2)-$ $\mathrm{N}(2)=2.002(5), \operatorname{Pt}(2)-\mathrm{N}(4)=1.993(5), \mathrm{Pt}(2)-\mathrm{N}(8)=2.040(5), \mathrm{Pt}(2)-$ $\mathrm{N}(9)=1.995(5), \operatorname{Pt}(1) \cdots \operatorname{Pt}(2)=3.417(1) \AA$.

tramolecular Pt $\cdots P t$ contact spanned the range 3.417(1)3.437(1) $\AA$, showing the presence of a minimum bonding interaction. In addition, the structural analyses of $\mathbf{6 a}$ confirm a virtual trans disposition, whereas the second isomer $\mathbf{6 b}$ showed a distinctive cis orientation for the fppz chelates that reside on two $\mathrm{Pt}(\mathrm{II})$ metal centers. Although $\mathbf{6 a}, \mathbf{b}$ were isolated in a yield of $22 \%$ and $45 \%$, respectively, the ${ }^{1} \mathrm{H}$ NMR analysis showed formation of 1:1 isomeric ratio prior to their isolation, suggesting the lack of any synthetic preference. This can probably be rationalized by the incorporation of only nitrogen donor atoms on the chelates amid the reaction. In sharp contrast, in other cyclometalated Pt complexes with either phosphido or pyrazolate bridges, it has been observed that the distinctive donor properties between the carbon and nitrogen donor atoms of cyclometalated chelates always place the high trans influence donor atoms in mutually trans position. ${ }^{22}$ Complexes $\mathbf{6 a}, \mathbf{b}$ are stable and are not interconvertible in toluene solution, as heating either sample at refluxing failed to induce the cis-trans isomerization but rather underwent decomposition within a period of $24 \mathrm{~h}$. A similar reaction pattern was observed for the dmpz analogues $\mathbf{7 a}, \mathbf{b}$, respectively.

(22) (a) Ma, B.; Li, J.; Djurovich, P. I.; Yousufuddin, M.; Bau, R.; Thompson, M. E. J. Am. Chem. Soc. 2005, 127, 28. 


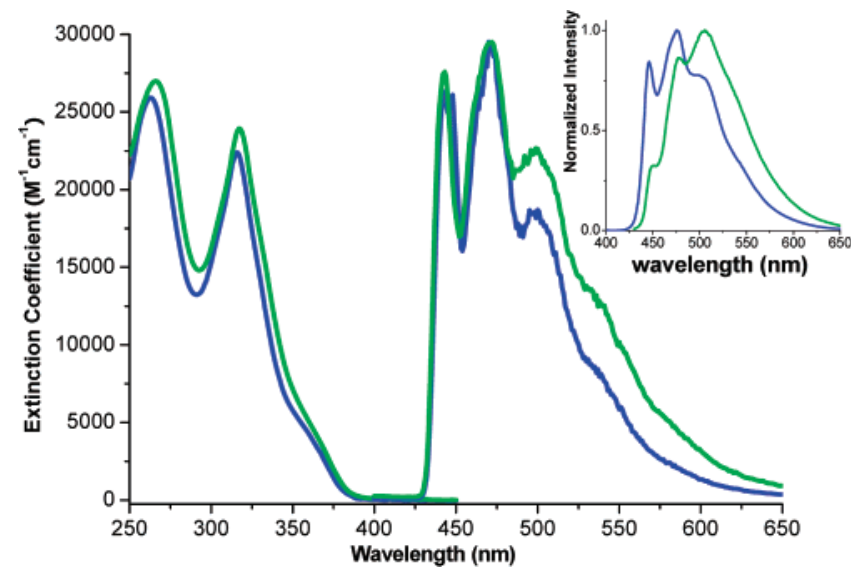

Figure 7. Absorption and emission spectra of complexes 6a (blue) and 6b (green) in $\mathrm{CH}_{2} \mathrm{Cl}_{2}$ solution recorded at ambient temperature (absorption) and $77 \mathrm{~K}$ (emission). Insert: Emission spectra of the respective complexes recorded from the vacuum-deposited thin films.

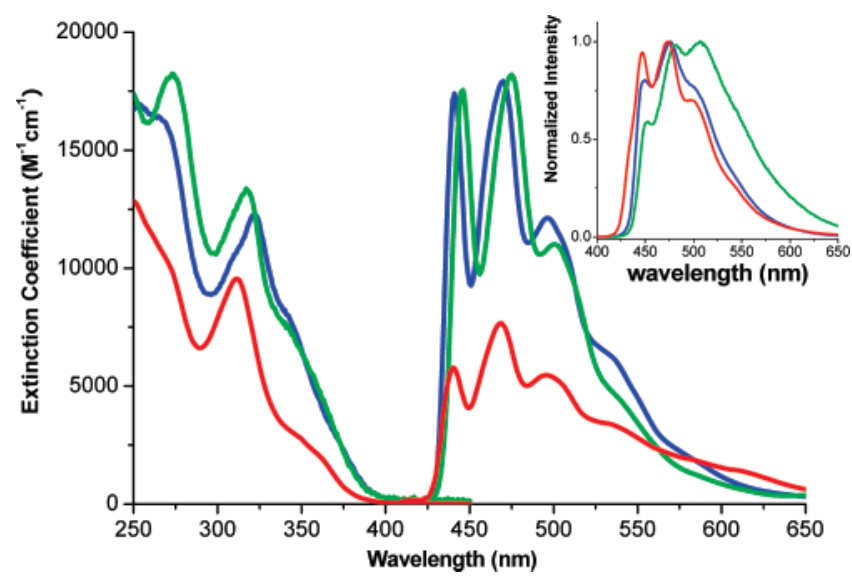

Figure 8. Absorption and emission spectra of $\mathbf{7 a}$ (blue), $\mathbf{7 b}$ (green), and 4 (red) in $\mathrm{CH}_{2} \mathrm{Cl}_{2}$ solution recorded at ambient temperature (absorption) and $77 \mathrm{~K}$ (emission). Insert: Emission spectra of the respective complex recorded from the vacuum-deposited thin films.

Photophysical Properties. The focus of this section is mainly on the dimeric platinum complexes due to their blueemitting properties. The absorption and emission spectra of complexes $\mathbf{6 a}, \mathbf{b}$ and $\mathbf{7 a}, \mathbf{b}$ are depicted in Figures 7 and 8 , respectively, while pertinent photophysical data are listed in Table 2. In general, the high-energy absorption bands at $\sim 320 \mathrm{~nm}$ of complexes $\mathbf{6}$ and $\mathbf{7}$ can be reasonably assigned to the azolate $\rightarrow$ pyridine intraligand $\pi \pi^{*}$ transition, which is also identified by their large extinction coefficients of $(1.2-2.4) \times 10^{4} \mathrm{M}^{-1} \mathrm{~cm}^{-1}$ as well as their spectral similarity with respect to the free ligand in the anionic form (not shown here). ${ }^{23}$ The next lower energy band with the peak wavelength at $\sim 350 \mathrm{~nm}$ is assigned to the spin-allowed ${ }^{1} \mathrm{MLCT}$ transition due to its relatively lower extinction coefficient of $<7 \times 10^{3} \mathrm{M}^{-1} \mathrm{~cm}^{-1}$. A supplementary support of these assignments is also provided by the computational approaches (vide infra). With the same molecular formula, the difference of absorption spectra between complexes a and b is small but nonnegligible (see Figure 7 or 8), implying

(23) (a) Cheng, C. C.; Yu, W. S.; Chou, P. T.; Peng, S. M.; Lee, G. H.; Wu, P. C.; Song, Y. H.; Chi, Y. Chem. Commun. 2003, 2628. (b) Wu, P. C.; Yu, J. K.; Song, Y. H.; Chi, Y.; Chou, P. T.; Peng, S. M.; Lee, G. H. Organometallics 2003, 22, 4938. that the orientation factor of the ligands may alter the electronic transition character for both isomers of $\mathbf{6}$ and $\mathbf{7}$. Moreover, in comparison to the mononuclear complex 4, the lower lying absorption of dinuclear complex $\mathbf{7 a}$ (or $\mathbf{7 b}$ ) is slightly red-shifted in peak wavelength and the associated extinction coefficient is approximately twice larger. These results suggested that the electronic transitions character of dinuclear complex 7a (or $\mathbf{7 b}$ ) can be qualitatively divided into two structural segments resemble that of $\mathbf{4}$, and the $\mathrm{Pt}-$ Pt interaction in the dinuclear complexes should be responsible for the observed small difference in energy gaps. More insight into these viewpoints is provided by the theoretical approaches.

We unfortunately could not resolve any emission for all isomeric complexes of $\mathbf{6}$ and 7 in the degassed $\mathrm{CH}_{2} \mathrm{Cl}_{2}$ solution at room temperature. Taking account of the sensitivity of current detecting system, the emission yield, if there is any, is concluded to be less than $10^{-4}$. Such an observation is similar to many $\mathrm{Pt}(\mathrm{II})$ complexes which are emissive in the solid state at RT and as glassy solution at lower temperature, whereas they are nonemissive in fluid solutions at RT. ${ }^{24}$ Perhaps, the quenching processes associated with, e.g., solvent collision and/or large amplitude motions can be drastically reduced by freezing solvent molecules at the cryogenic temperature or in a form of solid film. Supporting evidence is provided by the strong emission acquired in the $77 \mathrm{~K} \mathrm{CH}_{2} \mathrm{Cl}_{2}$ matrix as well as in the room-temperature solid film for both complexes 6 and 7 (see Figures 7 and 8). In solid film, the deduced radiative lifetime of microseconds for all isomers ensures the origin of emission from the triplet manifold, i.e., phosphorescence. The short radiative lifetime, in combination with the feature of vibronic progression in emission spectra, manifests the $T_{1}-S_{0}$ transition to be with ligand $\pi \pi^{*}$ properties mixed, in part, with the metal-to-ligand charge-transfer character (vide infra).

One remarkable feature revealed in Figures 7 and 8 lies in the emission spectral similarity between isomers $\mathbf{a}$ and $\mathbf{b}$ in $77 \mathrm{~K} \mathrm{CH}_{2} \mathrm{Cl}_{2}$ matrix in terms of peak wavelength and vibronic progression. In solid film, however, while the emission of the $\mathbf{a}$ isomer is similar to that in $77 \mathrm{~K} \mathrm{CH}_{2} \mathrm{Cl}_{2}$ matrix, notable spectral difference was observed for the $\mathbf{b}$ isomer (see inset of Figures 7 and 8), in which the vibronic ratio for the long wavelength versus the short wavelength band is greatly increased in the solid film. Since there is a lack of evidence on the intermolecular interaction for both $\mathbf{a}$ and $\mathbf{b}$ isomers in solid state (vide supra), the difference resulting from a packing or $\pi \pi$ stacking effect can be discarded. Alternatively, as previously proposed by Madigan et al., ${ }^{25}$ the results may be tentatively rationalized by the different sites that contribute to the neat films emission, i.e., the increased low-energy component present in the neat films of $\mathbf{b}$ as compared to $\mathbf{a}$ isomers. In a qualitative manner, such a composition variation may be rationalized by the difference in dipole moment between the symmetric isomer a $(\sim 1.0 \mathrm{D}$

(24) Kui, S. C. F.; Chui, S. S. Y.; Che, C. M.; Zhu, N. J. Am. Chem. Soc. 2006, 128, 8297.

(25) Madigan, C. F.; Bulović, V. Phys. Rev. Lett. 2003, 91, 247403. 
Chang et al.

Table 2. Photophysical Data of the Blue-Emitting Pt(II) Complexes $^{a}$

\begin{tabular}{|c|c|c|c|c|c|c|}
\hline complex & $\mathrm{UV} / \mathrm{vis}: \lambda_{\max },{ }^{b} \mathrm{~nm}\left(10^{-3} \epsilon, \mathrm{M}^{-1} \mathrm{~cm}^{-1}\right)$ & $\mathrm{em}: \lambda_{\max }, \mathrm{nm}^{c}$ & $\Phi,{ }^{c} \%$ & $\tau_{\mathrm{obs}},{ }^{c} \mu \mathrm{s}$ & $k_{\mathrm{r}}$ & $k_{\mathrm{nr}}$ \\
\hline 4 & $311(9.6), 342(3.2)$ & $(447,474,498),[440,468,496,534]$ & (38) & (7.4), [42.8] & $\left(5.1 \times 10^{4}\right)$ & $\left(8.4 \times 10^{4}\right)$ \\
\hline $6 \mathbf{a}$ & $263(25.9), 316(22.4), 355$ (5.1) & $(446,476,502),[445,470,500,540]$ & (55) & $(9.1),[20.9]$ & $\left(6.0 \times 10^{4}\right)$ & $\left(5.0 \times 10^{4}\right)$ \\
\hline $6 \mathbf{b}$ & $266(27.0), 318(23.9), 349$ (7.5) & $(451,478,506),[440,472,500,540]$ & $(28)$ & $(6.1),[20.8]$ & $\left(4.6 \times 10^{4}\right)$ & $\left(1.2 \times 10^{5}\right)$ \\
\hline $7 \mathbf{a}$ & $262(25.0), 322(12.3), 341(8.0)$ & $(450,476,502),[441,471,496,535]$ & (56) & (4.5), [20.6] & $\left(1.2 \times 10^{5}\right)$ & $\left(9.7 \times 10^{4}\right)$ \\
\hline $7 b$ & $273(18.2), 317$ (13.4), 343 (7.4) & $(453,479,506),[445,476,501,538]$ & (13) & $(0.53),[18.9]$ & $\left(2.4 \times 10^{5}\right)$ & $\left(1.6 \times 10^{6}\right)$ \\
\hline
\end{tabular}

${ }^{a} k_{\mathrm{r}}$ and $k_{\mathrm{nr}}$ were calculated according to the equations $k_{\mathrm{r}}=\Phi / \tau_{\mathrm{obs}}$ and $k_{\mathrm{nr}}=\left(1 / \tau_{\mathrm{obs}}\right)-k_{\mathrm{r} .}{ }^{b}$ Absorption spectra were recorded in $\mathrm{CH}_{2} \mathrm{Cl}_{2}$ solution. ${ }^{c} \mathrm{PL}$ data measured in solid film at room temperature and in $\mathrm{CH}_{2} \mathrm{Cl}_{2}$ matrix at $77 \mathrm{~K}$ are depicted in parentheses and brackets, respectively.

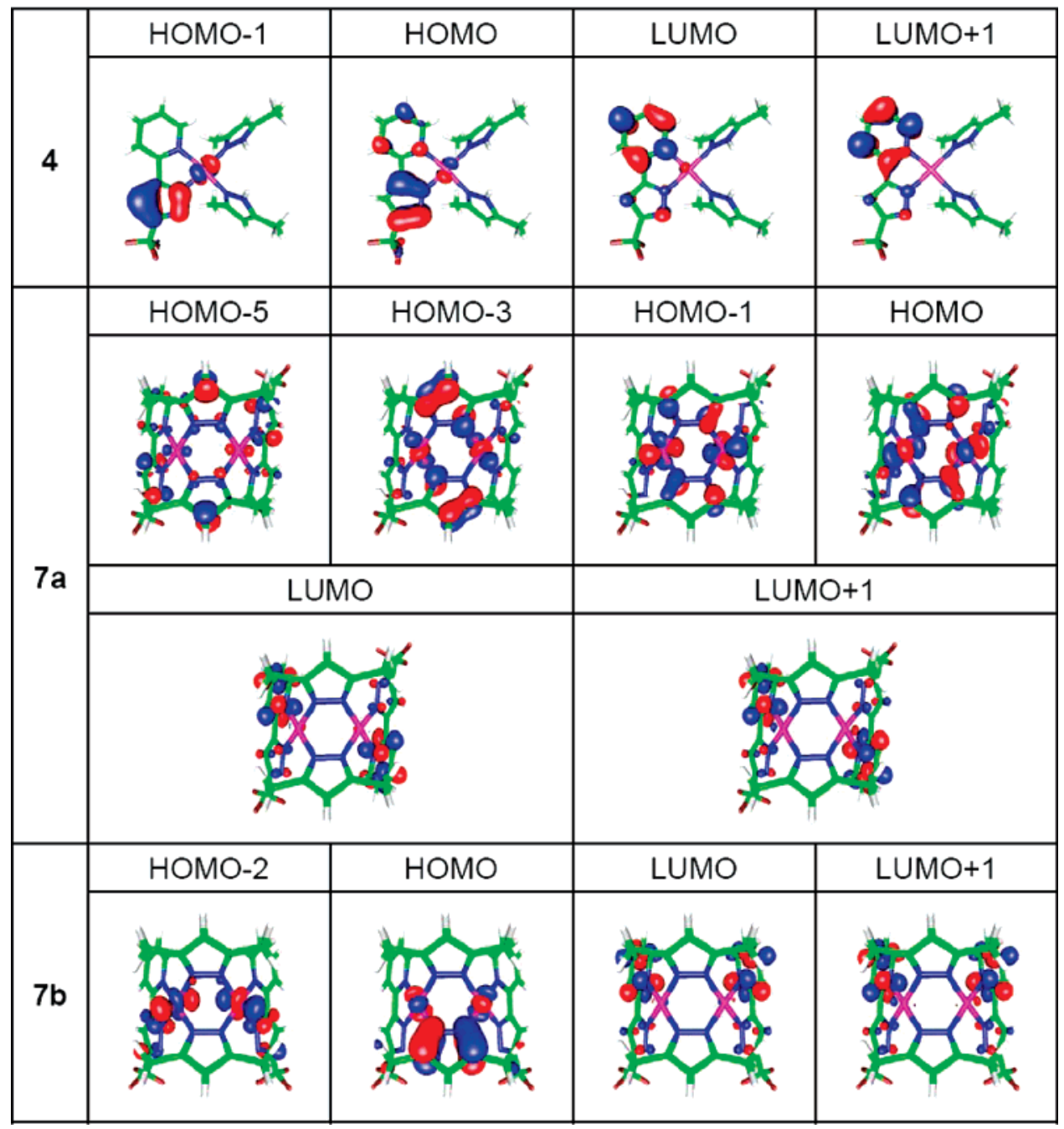

Figure 9. Frontier orbitals involved in the lowest lying singlet and triplet excited states for complexes $\mathbf{4}$ and $\mathbf{7 a}, \mathbf{b}$.

for $7 \mathbf{a})$ and the nonsymmetric $\mathbf{b}(\sim 6.1 \mathrm{D}$ for $\mathbf{7 b})$ estimated from the computational approaches.

Upon quick plunging of the sample (being diluted in $\mathrm{CH}_{2}-$ $\mathrm{Cl}_{2}$ ) into the liquid nitrogen environment, $\mathrm{Pt}(\mathrm{II})$ complexes 6 and 7 should exist in a well dispersed, monomeric form. It is thus reasonable to conclude negligible intermolecular $\mathrm{Pt}-\mathrm{Pt}$ nonbonding interaction for complexes $\mathbf{6}$ and $\mathbf{7}$ even in the solid film. If we know such interaction frequently takes place in $\mathrm{Pt}(\mathrm{II})$ complexes, ${ }^{26}$ the negligible $\mathrm{Pt}(\mathrm{II})$ packing interaction in solid film for $\mathbf{6}$ and $\mathbf{7}$ can be rationalized by the overall nonplanar structure, in which two Pt(II) units are spatially twisted with respect to each other, avoiding the

(26) Chang, S. Y.; Kavitha, J.; Li, S. W.; Hsu, C. S.; Chi, Y.; Yeh, Y. S.; Chou, P. T.; Lee, G. H.; Carty, A. J.; Tao, Y. T.; Chien, C. H. Inorg. Chem. 2006, 45, 137. intermolecular interaction. In a good correlation with the absorption spectra, the phosphorescence peak of $\mathbf{6 a}\left(\lambda_{\max }=\right.$ $476 \mathrm{~nm})$ and $7 \mathbf{a}\left(\lambda_{\max }=476 \mathrm{~nm}\right)$ in solid film is slightly blue-shifted with respect to that of $\mathbf{6 b}\left(\lambda_{\max }=478 \mathrm{~nm}\right)$ and $7 \mathbf{b}\left(\lambda_{\max }=479 \mathrm{~nm}\right)$. Furthermore, isomer $\mathbf{a}(\mathbf{6 a}, \Phi=0.55$; $7 \mathbf{a}, \Phi=0.56)$ is in higher emission quantum yield than that of $\mathbf{b}(\mathbf{6 b}, \Phi=0.28 ; 7 \mathbf{b}, \Phi=0.13)$. While the deduced radiative lifetime is similar in the same series (see Table 2), the higher emission quantum yield in series a is mainly due to its smaller nonradiative decay rate, $k_{\mathrm{nr}}$. For example, $k_{\mathrm{nr}}$ was deduced to be $1.6 \times 10^{6} \mathrm{~s}^{-1}$ for $\mathbf{7 b}$, which is larger than that $\left(9.7 \times 10^{4} \mathrm{~s}^{-1}\right)$ for $7 \mathbf{a}$ by 1 order of magnitude.

To gain insight into the above photophysical behavior, the electronic transition properties calculations of $\mathbf{4}$ and $\mathbf{7 a}, \mathbf{b}$ were performed using the density functional theory method 
Table 3. Calculated Energy Levels and Orbital Transition Analyses of $\mathbf{4}$ and 7a,b

\begin{tabular}{|c|c|c|c|c|c|}
\hline compd & state & $\lambda_{\text {cal }}, \mathrm{nm}$ & $f$ & assgnt & $\begin{array}{c}\text { MLCT } \\
\text { character, \% }\end{array}$ \\
\hline \multirow[t]{2}{*}{4} & $\mathrm{~T}_{1}$ & 438.3 & \multirow{3}{*}{0.0241} & $\mathrm{H} \rightarrow \mathrm{L}(+84 \%) ; \mathrm{H}-1 \rightarrow \mathrm{L}(+9 \%) ; \mathrm{H} \rightarrow \mathrm{L}+1(+6 \%)$ & 0.6 \\
\hline & $\mathrm{S}_{1}$ & 355.7 & & $\mathrm{H} \rightarrow \mathrm{L}(+80 \%) ; \mathrm{H}-1 \rightarrow \mathrm{L}(12 \%)$ & 0.6 \\
\hline $7 \mathbf{a}$ & $\mathrm{T}_{1}$ & 419.8 & & $\begin{array}{l}\mathrm{H}-3 \rightarrow \mathrm{L}(15 \%) ; \mathrm{H}-5 \rightarrow \mathrm{L}+1(14 \%) ; \mathrm{H}-3 \rightarrow \mathrm{L}+1 \\
\quad(+11 \%) ; \mathrm{H}-1 \rightarrow \mathrm{L}+1(10 \%) ; \mathrm{H}-5 \rightarrow \mathrm{L}(+10 \%) ; \\
\quad \mathrm{H}-1 \rightarrow \mathrm{L}(+7 \%) ; \mathrm{H}-2 \rightarrow \mathrm{L}(+7 \%) ; \mathrm{H}-6 \rightarrow \mathrm{L}(+7 \%)\end{array}$ & 11.6 \\
\hline \multirow{3}{*}{$7 \mathrm{~b}$} & $\mathrm{~S}_{1}$ & 364.4 & \multirow[t]{2}{*}{0.0644} & $\mathrm{H} \rightarrow \mathrm{L}(+68 \%) ; \mathrm{H}-1 \rightarrow \mathrm{L}(+16 \%) ; \mathrm{H}-2 \rightarrow \mathrm{L}+1(7 \%)$ & 26.7 \\
\hline & $\mathrm{T}_{1}$ & 423.8 & & $\begin{array}{l}\mathrm{H}-3 \rightarrow \mathrm{L}+1(+24 \%) ; \mathrm{H}-2 \rightarrow \mathrm{L}(23 \%) ; \mathrm{H}-5 \rightarrow \\
\quad \mathrm{L}+1(16 \%) ; \mathrm{H}-6 \rightarrow \mathrm{L}(+13 \%) ; \mathrm{H}-4 \rightarrow \mathrm{L}(+12 \%)\end{array}$ & 22.1 \\
\hline & $\mathrm{S}_{1}$ & 365.9 & 0.0611 & $\mathrm{H} \rightarrow \mathrm{L}(+45 \%) ; \mathrm{H}-2 \rightarrow \mathrm{L}(39 \%) ; \mathrm{H}-3 \rightarrow \mathrm{L}+1(+8 \%)$ & 22.9 \\
\hline
\end{tabular}

Table 4. Relative Energies and Percentile Contribution (\%) for the Molecular Orbitals of $\mathbf{7 a}, \mathbf{b}^{a}$

\begin{tabular}{llllllr}
\hline \multicolumn{7}{c}{ Complex 7a } \\
\hline \multicolumn{1}{c}{ param } & H-5 & H-3 & H-1 & HOMO & LUMO & L+1 \\
\hline rel energy (eV) & -6.31 & -6.13 & -6.02 & -5.9 & -1.96 & -1.89 \\
Pt (left) & 3.29 & 9.04 & 21.9 & 17.48 & 3.27 & 2.08 \\
Pt (right) & 3.33 & 10.69 & 21.88 & 17.4 & 3.12 & 2.26 \\
$\mathrm{CF}_{3}$-pyrazolate (left) & 22.22 & 9.74 & 6.9 & 10 & 8.25 & 7.37 \\
$\mathrm{CF}_{3}$-pyrazolate (right) & 22.54 & 11.12 & 6.72 & 9.95 & 7.73 & 7.93 \\
pyridyl (left) & 9.42 & 4.28 & 2.08 & 1.08 & 39.81 & 38.04 \\
pyridyl (right) & 9.55 & 4.91 & 2.07 & 1.09 & 37.05 & 40.82 \\
bridging pyrazolate & 14.81 & 23.16 & 19.53 & 21.56 & 0.39 & 0.74 \\
$\quad$ (bottom) & & & & & & \\
bridging pyrazolate & 14.84 & 27.05 & 18.93 & 21.43 & 0.39 & 0.77 \\
$\quad$ top) & & & & & &
\end{tabular}

Complex 7b

\begin{tabular}{lllllll}
\hline \multicolumn{1}{c}{ param } & H-5 & H-3 & H-2 & HOMO & LUMO & L+1 \\
\hline rel energy (eV) & -6.36 & -6.09 & -5.97 & -5.78 & -2.02 & -1.96 \\
$\mathrm{Pt}$ (left) & 5.55 & 11.32 & 23.37 & 9.22 & 3.04 & 2.24 \\
$\mathrm{Pt}$ (right) & 5.36 & 11.48 & 23.22 & 9.39 & 3.11 & 2.16 \\
$\mathrm{CF}_{3}$-pyrazolate (left) & 24.34 & 26.83 & 19.5 & 2.11 & 7.43 & 7.46 \\
$\mathrm{CF}_{3}$-pyrazolate (right) & 23.38 & 27.14 & 19.18 & 2.14 & 7.67 & 7.22 \\
pyridyl (left) & 7.16 & 6.12 & 3.17 & 0.82 & 38.35 & 40.38 \\
pyridyl (right) & 6.87 & 6.17 & 3.11 & 0.84 & 39.64 & 39.08 \\
$\begin{array}{l}\text { bridging pyrazolate } \\
\quad 1.88\end{array}$ & 0.36 & 2.15 & 71.49 & 0.51 & 0.83 \\
$\quad \begin{array}{l}\text { bottom) } \\
\text { bridging pyrazolate }\end{array}$ & 25.46 & 10.58 & 6.31 & 4 & 0.25 & 0.63 \\
$\quad$ (top) & & & & & &
\end{tabular}

${ }^{a}$ The definitions shown in the parentheses were assigned according to Figure 9.

(DFT). With the use of the TD-B3LYP method incorporating the obtained geometries from the structural optimization calculations, the vertical (i.e., Franck-Condon) excitation energy from the ground state to the lowest lying electronic excited state in both singlet and triplet manifolds was calculated. Figure 9 depicts the features of the two lowest unoccupied (LUMO and LUMO+1) and some highest occupied frontier orbitals for complexes 4 (HOMO and HOMO-1), 7a (HOMO, HOMO-1, HOMO-3, and HOMO5), and $\mathbf{7 b}$ (HOMO and HOMO-2), which are mainly involved in the $S_{1}$ and $T_{1}$ transitions. The assignments and the orbital energy gaps of $\mathbf{4}$ and $\mathbf{7 a}, \mathbf{b}$ are listed in Table 3 . Clearly, the calculated $S_{1}$ and $T_{1}$ energy levels for the titled complexes are qualitatively consistent with those $0-0$ onset of the absorption $\left(\mathrm{S}_{1}\right)$ and phosphorescence $\left(\mathrm{T}_{1}\right)$ spectra. Thus, the theoretical level adopted here should be suitable for studying the photophysical properties of these complexes in a qualitative manner.

For both complexes $\mathbf{7 a}, \mathbf{b}$, the excitations of the lowest triplet excited state $\left(T_{1}\right)$ are contributed by at least four possible transitions. Basically, the involved occupied orbitals are composed of those pyrazolate $\pi$ (in both bridging as well as chelating positions) and $\mathrm{Pt}(\mathrm{II}) \mathrm{d}_{\pi}$ orbitals, while the unoccupied orbitals are largely located at the pyridyl site. Thus, it seems unambiguous that the lowest lying transitions in both singlet and triplet manifolds are ascribed to interand intraligand $\pi \pi^{*}$ mixed with MLCT in character. As depicted in Figure 9, one can also envisage that HOMO orbitals of $\mathbf{7 b}$ are apparently much more located at one bridging pyrazolate moiety than that of $7 \mathbf{a}$. More careful examination pinpoints this bridging pyrazolate moiety in $\mathbf{7 b}$ to be in trans position with respect to both pyridyl groups and in cis position related to both pyrazolate fragments of the chelating ligands. This implies that the pyridyl fragments, due to their neutral property as well as the lack of $\mathrm{CF}_{3}$ substituent and an extra electronegative nitrogen atom, have less electron-withdrawing strength and hence their transpyrazolate bridge provides a much greater contribution to the HOMO. To support this viewpoint, the percentile contributions for both occupied and unoccupied orbitals involved in the low-lying excitations of $\mathbf{7 a}, \mathbf{b}$ are elucidated in Table 4. Obviously, the contribution of this bridging pyrazolate ligand in $\mathrm{HOMO}$ of $\mathbf{7 b}(\sim 72 \%)$ is 4 -fold greater than 7a $(\sim 20 \%)$.

In addition, other subtle differences in molecular framework may also cause discernible differences between $\mathbf{7 a}, \mathbf{b}$. Geometries optimization calculations show nonnegligible difference in $\operatorname{Pt}(1)-\operatorname{Pt}(2)$ distance between 7a,b. For example, the $\mathrm{Pt}(1)-\mathrm{Pt}(2)$ distance in $7 \mathbf{a}$ is measured to be 3.326 $\AA$, while it is a bit shorter $(3.359 \AA$ ) in $\mathbf{7 b}$. The role of Pt-

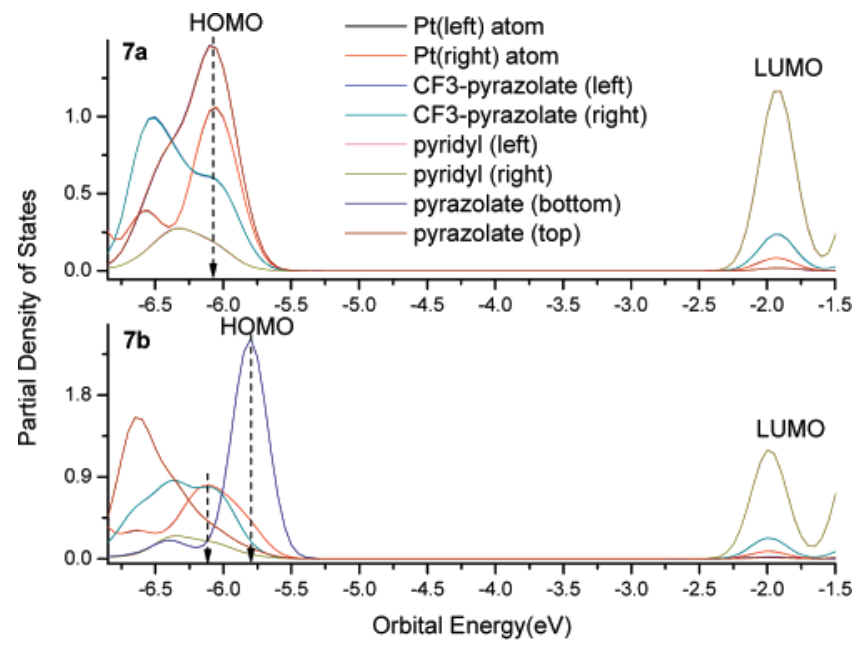

Figure 10. Plots of partial density of states of the representative complexes $7 \mathbf{a}, \mathbf{b}$. 
(1) $-\operatorname{Pt}(2)$ interaction in, e.g., 7a,b may be viewed from the corresponding mononuclear complex $\mathbf{4}$ that lacks similar interaction. For complex 4, as depicted in Figure 9, excitations of both the lowest singlet $\left(\mathrm{S}_{1}\right)$ and triplet $\left(\mathrm{T}_{1}\right)$ manifolds revealed a very similar pattern of transition with respect to that of 7, i.e., an intraligand $\pi \pi^{*}$ mixed with MLCT transition in character. However, complex 4 rendered a larger $\mathrm{S}_{0}-\mathrm{S}_{1}$ (or $\mathrm{S}_{0}-\mathrm{T}_{1}$ ) energy gap as compared to the dinuclear complexes 7 (See Table 3), the results of which manifest the subtle effect resulting from the $\mathrm{Pt}(1)-\mathrm{Pt}(2)$ interaction in the dinuclear complexes.

The nonnegligible $\operatorname{Pt}(1)-\operatorname{Pt}(2)$ interaction, in theory, should cause subtle difference in $\mathrm{Pt}(\mathrm{II}) \mathrm{d}_{\pi}$ orbitals. This viewpoint is further supported by the analyses of partial density of states depicted in Figure 10. The result clearly indicates that the major population of the density of states of central Pt(II) atoms in 7a moves downward in energy with respect to $\mathbf{7 b}$. This, in combination with the increase of bridging pyrazolate HOMO energy in $\mathbf{7 b}$, evidently renders a smaller $S_{0}-S_{1}$ (or $S_{0}-T_{1}$ ) energy gap for $\mathbf{7 b}$, consistent with the experimental observation (see Figure 8). Finally, the larger nonradiative decay rate $\left(k_{\mathrm{nr}}\right)$ in $\mathbf{b}$ series may be, in part, due to the relatively weak bridging pyrazolate-Pt(II) bonding strength, although a definitive proof is still pending. Of course, in comparison to $\mathbf{6 a}(\mathbf{7 a})$, the red shift of the emission peak wavelength and greatly extended red emission tail for $\mathbf{6 b}(\mathbf{7 b})$ (see Figures 7 and 8) may also account for the larger $k_{\text {nr }}$, i.e., the operation of energy gap law for the radiationless transition.

\section{Conclusion}

In summary, a new Pt(II) dichloride complex [Pt(fppzH)$\mathrm{Cl}_{2}$ ] (1) was prepared by the treatment of a pyridylpyrazole chelate fppzH with $\mathrm{K}_{2} \mathrm{PtCl}_{4}$ in aqueous $\mathrm{HCl}$ solution. Further treatment of complex 1 with pyrazole, 3,5-dimethylpyrazole, or even 3,5-di-tert-butylpyrazole has afforded the monometallic Pt(II) complexes $\mathbf{2}, \mathbf{3}, \mathbf{4}$, and 5a,b, showing a strong intra- or interligand hydrogen bonding occurred among the fppz chelate and corresponding monodentate pyrazolate ligand. Due to the greater rotational flexibility of the monodentate ligand, the majority of these complexes are nonemissive in both fluid and solid state at room temperature. To design the neutral Pt(II) complexes suited for showing blue emission, complex 2 (or 3) was further treated with excess of base to afford two isomeric complexes with formula $\mathbf{6 a}, \mathbf{b}(\mathbf{7 a}, \mathbf{b})$, which are related to each other according to the spatial orientation of the bidentate fppz chelates, i.e., trans- and cis-isomerism. Both 6a,b (7a,b) show a twisted dimeric framework. This, in combination with the bridging pyrazolate chelate that disrupts the formation of $\pi \pi$ stacking in solid state, renders a prototypical model to reduce the intermolecular interaction, such that highly emissive phosphorescence in blue can be achieved.

Acknowledgment. We thank the support from the following research grants: NSC 96-2628-M-007-018; NSC 962881-M-007-018; 94-EC-17A-08-S1-042.

Supporting Information Available: X-ray crystallographic data files (CIF) of complexes $\mathbf{2}, \mathbf{4}, \mathbf{5 a}, \mathbf{b}$, and $\mathbf{6 a}, \mathbf{b}$. This material is available free of charge via the Internet at http://pubs.acs.org.

IC701586C 